\title{
Recent advances of trilobite research in Korea: Taxon- omy, biostratigraphy, paleogeography, and ontogeny and phylogeny
}

\author{
Duck K. Choi ${ }^{1}$ and Tae-Yoon S. Park ${ }^{2 *}$ \\ ${ }^{1}$ Research Institute of Basic Sciences, Seoul National University, Seoul 08826, Republic of Korea \\ ${ }^{2}$ Division of Polar Earth-System Sciences, Korea Polar Research Institute, Incheon 21990, Republic of Korea
}

\begin{abstract}
Trilobites are among the most diverse and abundant fossil groups in Korea and occur in the Cambrian-Ordovician Joseon Supergroup of the Taebaeksan Basin. The Cambrian-Ordovician trilobites of the Joseon Supergroup have been intensively studied during the last quarter century, with emphasis on taxonomic revision, refining biostratigraphic zonation, paleogeographic implications, and ontogeny and phylogeny. A total of 243 species have hitherto been known to occur in the Joseon Supergroup of the Taebaeksan Basin: 118 and 110 species were reported in the Taebaek and Yeongwol groups, respectively, whilst 15 species were described from the Mungyeong Group. Contrasting trilobite faunal contents of the Taebaek and Yeongwol/Mungyeong groups resulted in two separate biostratigraphic schemes for the Cambrian-Ordovician of the Taebaeksan Basin: 22 biozones or fossiliferous horizons were recognized in the Taebaek Group; 19 zones were established in the Yeongwol Group; and four biozones were known from the Mungyeong Group. These trilobite biozones of the Taebaeksan Basin can be correlated well with those of North China, South China, and Australia. The distribution of some of the Cambrian and Ordovician endemic trilobites and the detrital zircon spectra of the pertinent areas suggest that the Sino-Korean Craton was located at the margin of east Gondwana and was separated from the South China Craton by an oceanic basin, and that the Taebaeksan Basin was a part of an epeiric sea in east Gondwana. Focus of the ontogenetic research of Korean trilobites was initially on the Cambrian trilobites from the Machari Formation of the Yeongwol Group, and then, was shifted to the silicified sclerites dissolved out of the carbonates of the Guzhangian to Tremadocian strata of the Taebaek Group, which have played a crucial role in resolving the trilobite phylogeny. Still, much of the carbonate strata of the Taebaek Group containing silicified trilobites has remained unstudied. The future ontogenetic research on the trilobites from the middle Cambrian (Cambrian Series 3) and the Furongian strata of the Taebaek Group would significantly contribute to elucidating the muddled trilobite phylogeny.
\end{abstract}

Key words: trilobites, Joseon Supergroup, Cambrian-Ordovician, Taebaeksan Basin, Sino-Korean craton, ontogeny

Manuscript received March 23, 2017; Manuscript accepted August 12, 2017

\section{INTRODUCTION}

Trilobites are among the most diverse and abundant fossil groups in Korea. They occur mainly in the Cambrian-Ordovician Joseon Supergroup of the Taebaeksan Basin in the mid-eastern part of the Korean Peninsula (Fig. 1). The lower Paleozoic Joseon Supergroup is a mixed siliciclastic-carbonate succession that ranges from the Cambrian Series 2 to Middle Ordovician.

\section{*Corresponding author:}

Tae-Yoon S. Park

26 Songdomirae-ro, Yeonsu-gu, Division of Polar Earth-System Sciences, Korea Polar Research Institute, Incheon 21990, Republic of Korea Tel: +82-32-760-5437, Fax: +82-32-770-5494, E-mail: typark@kopri.re.kr

(C)The Association of Korean Geoscience Societies and Springer 2017
The Joseon Supergroup is divided into three groups, i.e., the Taebaek, Yeongwol, and Mungyeong groups (Choi, 2014; Choi et al., 2016). The Taebaek and Yeongwol groups yield diverse and abundant trilobites, while the Mungyeong Group is poorly fossiliferous.

During the first half of the $20^{\text {th }}$ Century, knowledge on the lower Paleozoic trilobites of Korea was mainly assembled by a Japanese paleontologist, Teiichi Kobayashi. Kobayashi (1966) compiled the Cambrian-Ordovician faunas of South Korea, in which more than 200 species of trilobites were listed from 16 trilobite biozones of the Taebaek Group, nine biozones of the Yeongwol Group, and four biozones of the Mungyeong Group. Historical review on the trilobite studies in Korea during the $20^{\text {th }}$ Century has been thoroughly treated by Choi (2007). Over 


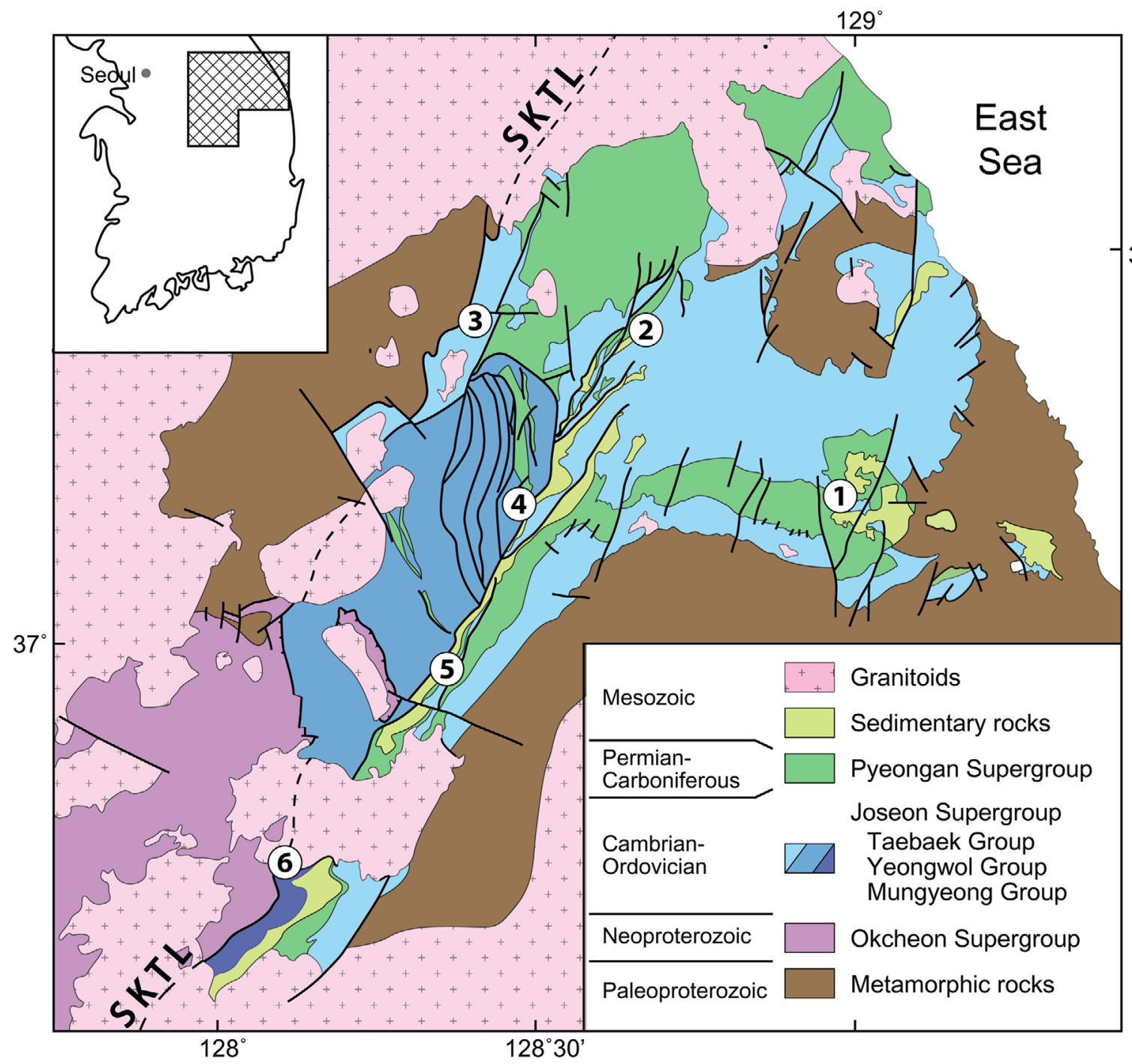

Fig. 1. Simplified geologic map of the Taebaeksan Basin, Korea. SKTL - South Korean Tectonic Line. Numbers in circle denote: 1, Taebaek; 2, Jeongseon; 3, Pyeongchang: 4, Yeongwol; 5, Danyang; 6, Mungyeong. The sedimentary rocks include volcanics and pyroclastic sedimentary rocks. Modified from Choi et al. (2016).

the last quarter century, the Cambrian-Ordovician trilobites of the Joseon Supergroup have been intensively re-evaluated on the basis of a number of new fossil collections, which have contributed in various aspects of trilobite research. The main purpose of this paper is to review the achievement of trilobite studies in Korea over the last quarter century, with special emphasis on the contribution in taxonomy, biostratigraphy, paleogeography, and ontogeny and phylogeny.

\section{GEOLOGY AND STRATIGRAPHY}

It has been well appreciated that the mainland China was formed by amalgamation of the Sino-Korean and South China cratons in the early Triassic (Dong et al., 2011; Wu and Zheng, 2013). The Sino-Korean Craton (SKC) is composed mostly of
North China and parts of the Korean Peninsula, while the South China Craton (SCC) consists mostly of South China and middle part of the Korean Peninsula (Chough et al., 2000; Fig. 2a). The Korean Peninsula is divided tectonically into the northern, central, and southern blocks and is further subdivided into eleven tectonic provinces (Choi, 2014; Fig. 2b): the northern block includes the Kwanmo Massif, Machollyong Belt, Rangnim Massif, and Pyongnam Basin; the central block comprises the Imjingang Belt, Gyeonggi Massif, and Chungcheong Basin; the southern block consists of the Taebaeksan Basin, Yeongnam Massif, and Gyeongsang Basin; the Dumangang Belt is regarded as an independent tectonic province; and the Okcheon Belt is considered a composite tectonic collage formed by amalgamation of two tectonic provinces with different origins, i.e., the Chungcheong and Taebaeksan basins. Prior to the Mesozoic, the northern and 

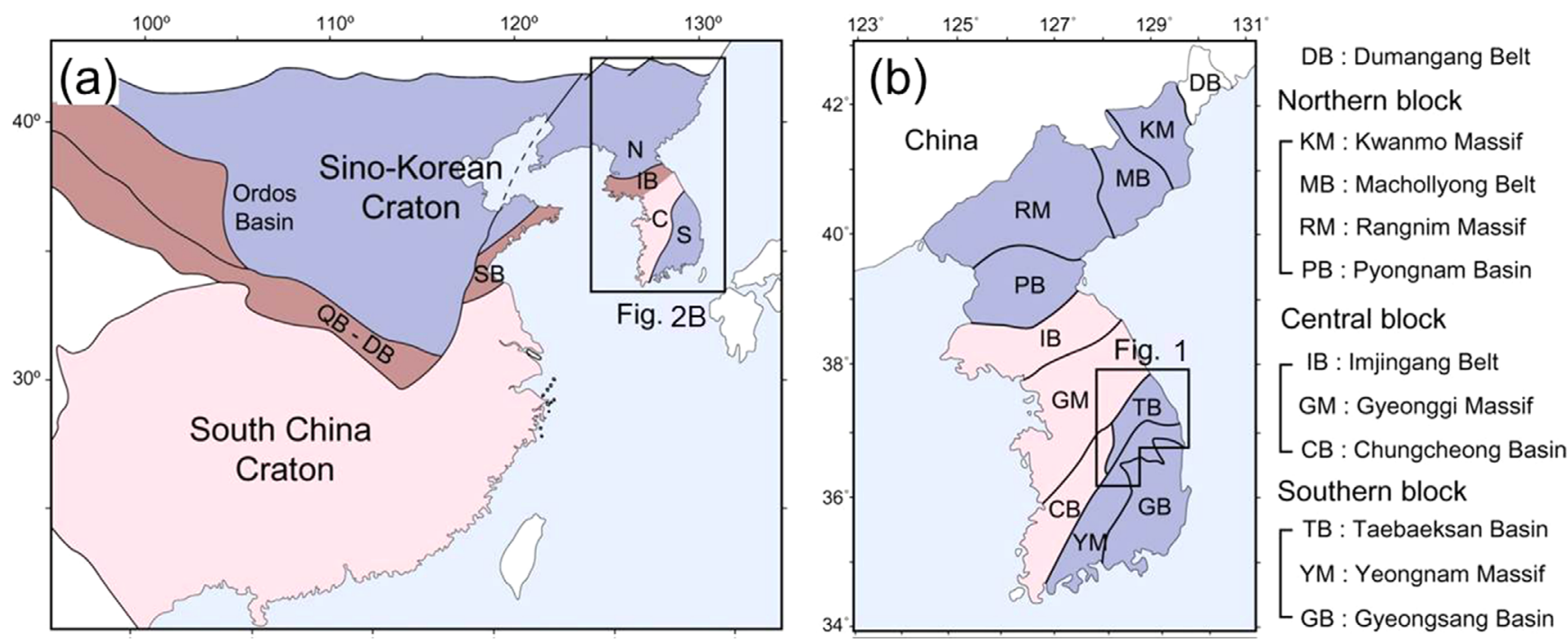

Fig. 2. Index maps. (a) Simplified tectonic map of East Asia (modified from Wu and Zheng, 2013; Choi, 2014). Abbreviations: $C$ - central block, DB - Dabie Belt, IB - Imjingang Belt, N - northern block, QB - Qinling Belt, S - southern block, SB - Sulu Belt. (b) Tectonic blocks and provinces of the Korean Peninsula. Note the approximate location of Figure 1.

southern blocks belonged to the Sino-Korean Craton, whilst the central block was part of the South China Craton.

The Taebaeksan Basin is a tectonic province occupying the northern part of the southern block of the Korean Peninsula and consists mainly of the lower Paleozoic Joseon Supergroup and the upper Paleozoic Pyeongan Supergroup (Fig. 1). The Joseon Supergroup is unconformably underlain by the Paleoproterozoic basement composed largely of granitic gneiss and metasedimentary rocks, and is in turn overlain by the upper Paleozoic Pyeongan Supergroup. The two supergroups are separated by a disconformity representing a 140-myr-long time span. The lower Paleozoic Joseon Supergroup consists predominantly of carbonate with subordinate sandstone and shale. Detailed description on the lithostratigraphy of the Joseon Supergroup was given by Choi and Chough (2005).

In the early Paleozoic, the Taebaeksan Basin was a shallow marine mixed siliciclastic-carbonate system with progressively greater depth of water to the southwest (Yeongwol and Mungyeong areas), as indicated by the occurrence of coarse-grained siliciclastic successions (Jangsan and Myeonsan formations) along the eastern margin of the Taebaeksan Basin (Chough et al., 2000). This siliciclastic-carbonate system maintained throughout the Cambrian, but rapid accumulation of carbonate sediments in the Yeongwol area in the latest Cambrian resulted in forming a widespread carbonate platform across the Taebaeksan Basin. Accordingly, the Taebaeksan Basin was transformed into a shallow marine setting with shoals, lagoons, and tidal flats in the Early to Middle Ordovician (Choi et al., 2001). Early Paleozoic marine sedimentation ceased over much of the Taebaeksan Basin in the Late Ordovician, whilst Late Ordovician volcanism affected the Mungyeong area. The Late Ordovician volcanism suggests the timing for breakup and eventual departure of the Sino-Korean Craton from core Gondwana by the end of Ordovician (Cho et al., 2014). Subsequently, the Taebaeksan Basin became a part of the isolated drifting land mass during the mid-Paleozoic until it finally collided with the South China Craton in the early Triassic (Choi, 2014).

The Taebaek Group refers to the Cambrian-Ordovician succession exposed in the eastern and northern parts of the Taebaeksan Basin, which is bounded to the southwest by major thrust faults (Choi and Chough, 2005; Fig. 1). Choi (2014) regarded the Yongtan and Pyeongchang groups as lateral equivalents of the Taebaek Group. The Taebaek Group has been divided into, in ascending order, the Jangsan/Myeonsan, Myobong, Daegi, Sesong, Hwajeol, Dongjeom, Dumugol, Makgol, Jigunsan, and Duwibong formations (Choi, 1998a; Fig. 3). Sedimentological studies revealed that the Taebaek Group had formed in a low-relief, mixed carbonate-siliciclastic setting, influenced strongly by sea-level fluctuations (Choi et al., 2004a; Kwon et al., 2006). Twenty-two trilobite biozones have been established within the Taebaek Group (Fig. 3), which constrain the geologic age of the group from the Cambrian Series 2 to the Middle Ordovician (Choi et al., 2016).

The Yeongwol Group occupies the western half of the Taebaeksan Basin, bounded to the east by the Deokpori thrust, to the north by the Sangni thrust, and to the west by the Bonghwajae thrust. The geologic structure of the Yeongwol Group is strongly governed by a number of imbricated thrust faults (Choi, 1998a; Fig. 1). The Yeongwol Group is divided into the Sambangsan, Machari, Wagok, Mungok, and Yeongheung formations, in 


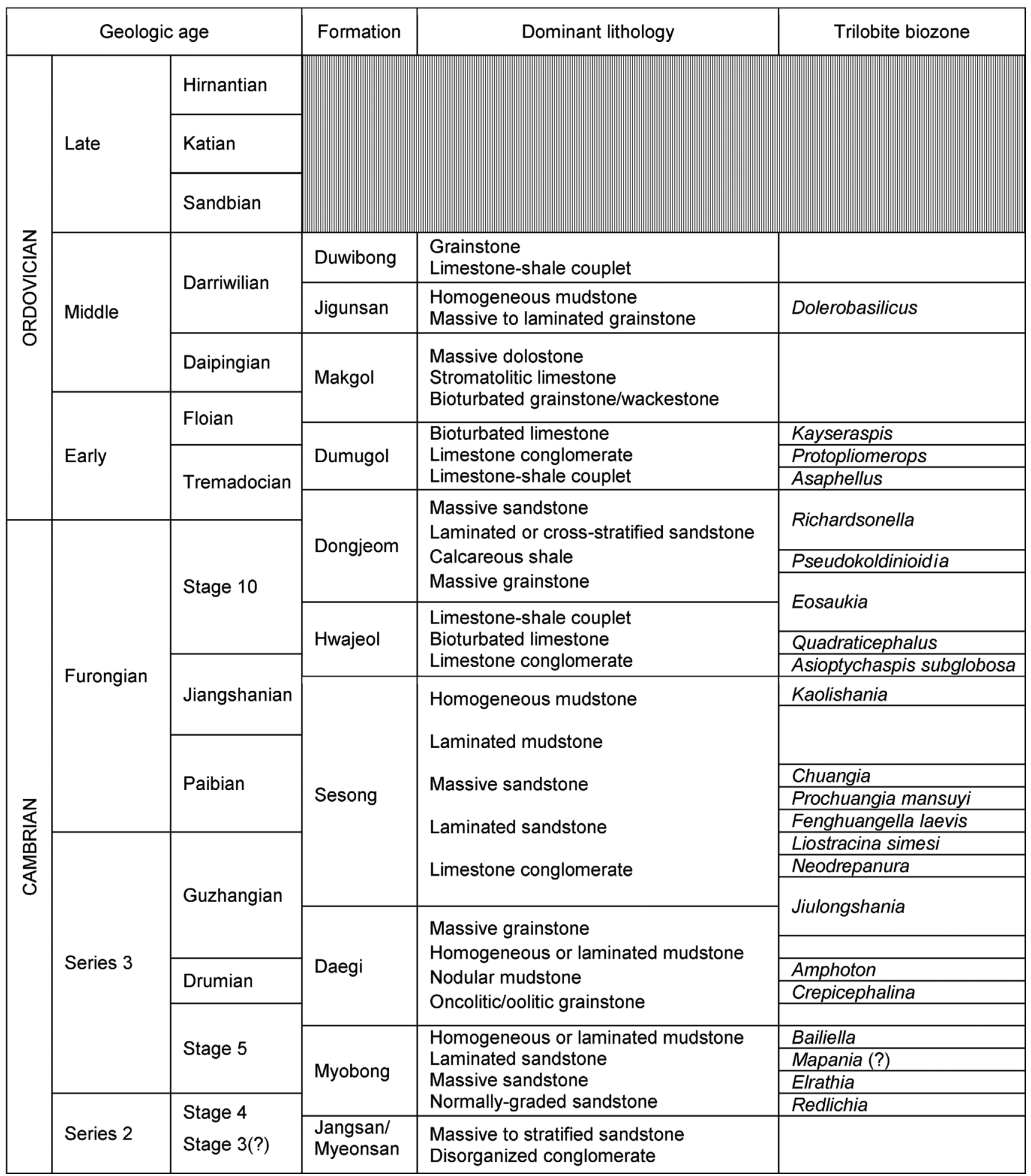

Fig. 3. Lithostratigraphic and biostratigraphic summary of the Taebaek Group, Taebaebksan Basin, Korea. Modified from Choi et al. (2016). The arrangement of dominant lithologies within each formation does not reflect stratigraphic order.

ascending order (Yosimura, 1940; Choi, 1998a; Fig. 4). The lowermost Sambangsan Formation consists exclusively of siliciclastic deposits, whereas the upper four formations are composed predominantly of carbonates. Nineteen trilobite zones are established in the
Yeongwol Group (Fig. 4) and the geologic age of the group has been bracketed within the Cambrian Series 2 to the Middle Ordovician (Choi et al., 2016).

The Mungyeong Group refers to the Cambrian-Ordovician 


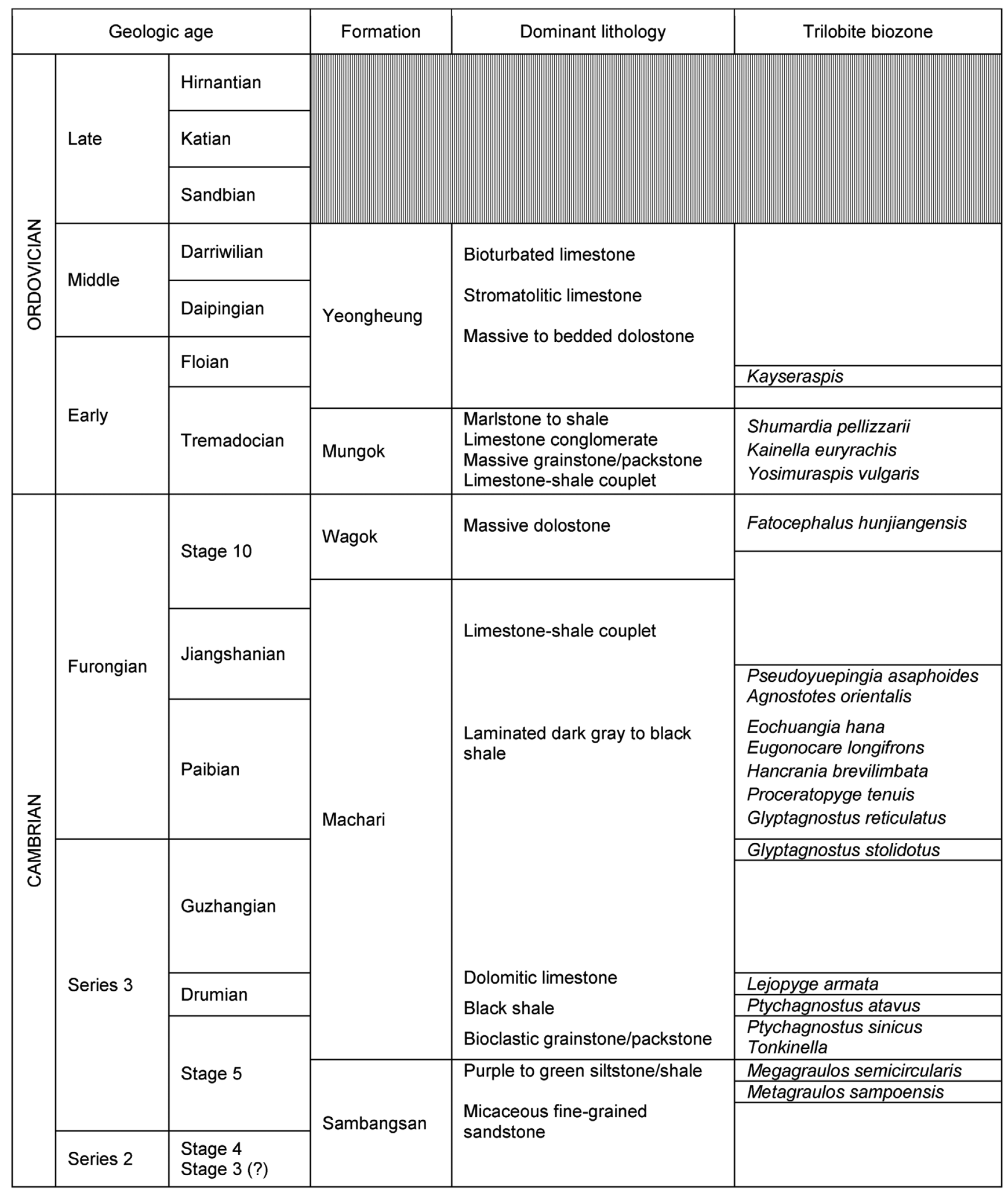

Fig. 4. Lithostratigraphic and biostratigraphic summary of the Yeongwol Group, Taebaebksan Basin, Korea. Modified from Choi et al. (2016). The arrangement of dominant lithologies within each formation does not reflect stratigraphic order.

strata exposed in the Mungyeong area (Fig. 1). It occurs in the southernmost corner of the Taebaeksan Basin, bounded to the east by the Seokhyeon thrust and to the west by the Sangnaeri thrust (Kobayashi et al., 1942). The Mungyeong Group has not been studied in detail yet and is generally subdivided into the Gurangni Formation in the lower and the undifferentiated carbonate 
formation in the upper (Choi, 1998a). The Mungyeong Group is overlain by the Upper Ordovician Ongnyeobong Formation (Cho et al., 2014).

\section{TAXONOMY}

In an earlier comprehensive compilation of the CambrianOrdovician faunas of South Korea (Kobayashi, 1966), 279 trilobite species belonging to 133 genera were listed from the Joseon Supergroup. However, the number of trilobite species has been reduced considerably by the taxonomic revision of the trilobite faunas of the Taebaeksan Basin during the last quarter century: A total of 243 species have been recognized from the Joseon Supergroup: 118 and 110 species were reported in the Taebaek and Yeongwol groups, respectively, whilst 15 species were described from the Mungyeong Group.

The list of the trilobite species documented in the lithologic units (formations) of the Taebaek, Yeongwol, and Mungyeong groups are presented herein; the formations are arranged in stratigraphyically ascending order, and the trilobite species occurring within a lithologic unit are listed in alphabetical order of genera. The species occurring across the formation boundary are listed only for the underlying formation. Trilobites from the Myobong and Duwibong formations of the Taebaek Group and those of the Mungyeong Group were not revised during the past quarter century and thus follow the list of Kobayashi (1961; 1966).

\subsection{Taebaek Group}

Myobong Formation (4 species): Bailiella angusta, Kobayashi, 1960b; Elrathia taikiensis Kobayashi, 1935; Mapania beihoensis Kobayashi, 1935; Redlichia saitoi Lu, 1950.

Daegi Formation (19 species): Ammagnostus laiwuensis (Lorenz, 1906); Ammagnostus sp. 1; Amphoton deois (Walcott, 1905); Anomocarella temenus (Walcott, 1905); Bergeronites ketteleri (Monke, 1903); Blackwelderia sp. 2; Blackwelderia sp. 3; Changqingia deprati (Kobayashi, 1935); Crepicephalina damia (Walcott, 1905); Dorypyge richthofeni Dames, 1883; Ignotogregatus sp. cf. I. manholi Zhang and Jell, 1987; Jiulongshania longispina (Wittke and Zhu in Zhu and Wittke, 1989); Jiulongshania rotundata (Resser and Endo, 1937); Jiulongshania sp. 1; Manchuriella macar (Walcott, 1911); Metanomocarella tumida (Resser and Endo, 1937); Palaeadotes? sp. 1; Proasaphiscus sp. 1; Teinistion sp. 1.

Sesong Formation (40 species): Acanthometopus sp. 1; Alataspis sesongensis Park and Choi, 2011b; Baikadamaspis jikdongensis Park and Choi, 2011b; Baikadamaspis sp. 1; Blackwelderia sp. 1; Ceratopygid sp. 1; Ceratopygid sp. 2; Chuangia sp. 1; Damesellid sp. 1; Damesellid sp. 2; Elaphraella microforma Lu and Qian, 1983;
Elaphraella nodus (Qian, 1994); Elaphraella? taebaeksanensis Park and Choi, 2012a; Fenghuangella laevis Park and Choi, 2011b; Gumunsoia triangularis Park, Sohn and Choi, 2012; Gumunsoia sp. 1; Hebeia sp. 1; Huzhuia sp. 1.; Huzhuia sp. 2; Jiulongshania regularis (Walcott, 1906); Kaolishania granulosa Kobayashi, 1933; Kaolishaniid genus and species indeterminate 1; Lingyuanaspis sp. 1; Liostracina simesi Jago and Cooper, 2005; Liostracina sp. cf. L. bilimbata Zhang in Qiu et al., 1983; Liostracina sp. 1; Maladioides coreanicus Kobayashi, 1935; Monkaspis sp. 1; Neodrepanura sp. 1; Pagodia sp. cf. P. spina Qian, 1994; Parachangshania monkei (Kobayashi, 1935); Parachangshania rectangularis Park and Choi, 2011b; Placosema bigranulosum Peng et al., 2004; Prochuangia mansuyi Kobayashi, 1935; Shirakiella elongata Kobayashi, 1935; Shirakiella sp. 1; Taishania? sp. 1; Stephanocare richthofeni Monke, 1903; Teinistion lansi Monke, 1903; Teinistion sp. 2.

Hwajeol Formation (31 species): Akoldinioidia latus Park and Kihm, 2015a; Asioptychaspis subglobosa (Sun, 1924); Baikadamaspis sp. 2; Caznaia coreaensis Park and Kihm, 2015a; Changia sp. 1; Eosaukia acuta (Kuo and Duan in Duan et al., 1986); Eosaukia bella (Walcott, 1906); Eosaukia micropora (Qian, 1985); Guangxiaspis sp. 1; Gumunsoia sp. 2; Haniwa quadrata Kobayashi, 1933; Hamashania pulchera Kobayashi, 1942a; Hamashania sp. cf. $H$. busiris (Walcott, 1905); Haniwa sosanensis Kobayashi, 1933; Koldinioidia choii Park and Kihm, 2015a; Koldinioidia sp. 1; Lophosaukia orientalis (Kobayashi, 1933); Lophosaukia? sp. 1; ?Mansuyia sp. 1; Micragnostus sp. 1; Mictosaukia sp. cf. M. globosa (Robison and Pantoja-Alor, 1968); Parakoldinioidia sp. 1; Pseudagnostus planulatus (Raymond, 1924); Pseudokoldinioidia sp. cf. P. granulosa Endo, 1944; Ptycahspidid sp. 1; Quadraticephalus elongatus Kobayashi, 1935; ?Saukia aojii Kobayashi, 1933; Taebaeksaukia spinata Lee and Choi, 2011; Tsinania canens (Walcott, 1905); Tsinania sp. 1; Wuhuia bellus (Walcott, 1905).

Dongjeom Formation (11 species): Apatokephalus latilimbatus Peng, 1990; Koldinioidia typicalis Kobayashi, 1931; Leiostegiid sp. 1; Micragnostus chiushuensis (Kobayashi, 1931); Micragnostus sp. 1; Onychopyge borealis Zhou and Zhang, 1978; Pilekiid sp. 1; Platypeltoides sp. 1; Pseudokoldinioidia perpetis (Zhou and Zhang, 1985); Richardsonella sp. 1; Yosimuraspis sp. 1.

Dumugol Formation (7 species): Apatokephalus latilimbatus Peng, 1990; Apatokephalus? sp. 1; Asaphellus tomkolensis Kobayashi, 1934b; Asaphellus coreanicus Kobayashi, 1934b; Asaphopsoides nakamurai (Kobayashi, 1936); Hystricurus sp. 1; Kayseraspis laticauda (Kobayashi, 1934b).

Jigunsan Formation (4 species): Basiliella kawasakii Kobayashi, 1934a; Basiliella typicalis (Kobayashi, 1934a); Dolerobasilicus yokusensis (Kobayashi, 1934a); Ptychopyge dongjeomensis Lee and Cheong in Lee et al., 1980.

Duwibong Formation (2 species): Basiliella lorenzi Kobayashi, 1934a ; Pliomera aff. Martellii Reed, 1917. 


\subsection{Yeongwol Group}

Sambangsan Formation (2 species): Megagraulos semicircularis Kobayashi, 1961; Metagraulos sampoensis Kobayashi, 1961.

Machari Formation (77 species): Acmarhachis typicalis (Resser, 1938); Agnostid sp. 1; Agnostotes orientalis (Kobayashi, 1935); Ammagnostus serus Choi et al., 2004b; Ammagnostid sp. 1; Aspidagnostus stictus Öpik, 1967; Changshania equalis Sun, 1935; Chuangia spp:; Clavagnostid sp. 1; Cyclolorenzella? sp. 1; Dikelocephalites flabelliformis Sun, 1935; Diplagnostus planicauda (Angelin, 1851); Eochuangia hana Kobayashi, 1935; Eoshengia? sp. 1; Erixanium similis (Kobayashi, 1962); Erixanium sp. 1; Eugonocare longifrons (Kobayashi, 1935); Glyptagnostus reticulatus (Angelin, 1851); Glyptagnostus stolidotus Öpik, 1961; Hancrania brevilimbata Kobayashi, 1962; Haniwoides longus Kobayashi, 1935; Homagnostus obesus (Belt, 1867); Homagnostus? sulcatus Choi et al., 2004b; Hypagnostus parvifrons (Linnarsson, 1869); Innitagnostus innitens Öpik, 1967; Innitagnostus sp. 1; Irvingella convexa (Kobayashi, 1935); Irvingella coreanica Hong et al., 2003b; Irvingella major Ulrich and Resser in Walcott, 1924; Irvingella megalops (Kobayashi, 1962); Irvingella typa (Kobayashi, 1935); Ivshinagnostus alatus Choi et al., 2004b; Ivshinagnostus hunanensis (Peng, 1992); Ivshinagnostus quadratus Choi et al., 2004b; Jingxiania sp. cf. J. beigongliensis Chien in Lu et al., 1974; Joshuaspis parvus Choi et al., 2008; Kormagnostella sp. 1; Kormagnostus inventus (Shergold, 1982); Kormagnostus minutus (Schrank, 1975); Lejopyge armata (Linnarsson, 1869); Lisogoragnostus coreanicus Hong et al., 2003a; Lisogoragnostus minor (Kobayashi, 1962); Macharia pengi Choi et al., 2008; Metachangshania brachypyga Choi et al., 2008; Metachangshania sp. 1; Micragnostus elongatus (Chien, 1961); Micragnostus hisakoshii (Kobayashi, 1962); Micragnostus aff. intermedius (Palmer, 1968); Nahannagnostus nganasanicus (Rozova, 1964); Nahannagnostus pratti Choi et al., 2004b; Olenus asiaticus Kobayashi, 1944; Olenid sp. 1; Peratagnostus obsoletus (Kobayashi, 1935); Peratagnostus orientalis (Lazarenko, 1966); Peronopsis taitzuhoensis Lu, 1957; Proceratopyge elongata Lee \& Choi, 1995; Proceratopyge praelonga Lee and Choi, 1995; Proceratopyge promisca Choi et al., 2008; Proceratopyge rectispinata (Troedsson, 1937); Proceratopyge tenuis (Kobayashi, 1962); Pseudagnostus? dividuus Choi et al., 2004b; Pseudagnostus idalis Öpik, 1967; Pseudagnostus josepha (Hall, 1863); Pseudagnostus medius Choi et al., 2004b; Pseudagnostus securiger (Lake, 1906); Pseudagnostus sp. 1; Pseudengonocare bispinatum (Kobayashi, 1962); Pseudorhaptagnostus tumidus (Sun, 1989); Pseudorhaptagnostus urceus Choi et al., 2004b; Pseudoyuepingia asaphoides (Kobayashi, 1962); Ptychagnostus atavus (Tullberg, 1880); Ptychagnostus sinicus Lu, 1957; Stigmatoa coreanica (Kobayashi, 1962); Wuhuia sp. 1; Yakutiana ovale (Yang, 1982); Yongwolagnostus dubius Choi et al, 2004b; Yongwolagnostus stenorhachis Choi et al., 2004b.
Wagok Formation (7 species): Amzasskiella? sp. 1; Fatocephalus hunjiangensis Duan and An in Kuo et al., 1982; Hysterolenus sp. 1; Koldinioidia longa Lu and Lin, 1984; Micragnostus aff. elongatus (Chien, 1961); Micragnostus sp. 1; Pseudorhaptagnotus kentauensis (Ergaliev, 1980).

Mungok Formation (20 species): Agnostid sp. 2; Apatokephalus hyotan Kobayashi, 1953; Asaphellus sp. 1; Asaphellus sp. 2; Asaphid sp. 1; Dikelokephalina asiatica Kobayashi, 1934b; Elkanaspis jilinensis Qian in Chen et al., 1985; Hukasawaia cvlindrica (Kobayashi, 1953); Hystricurus sp. cf. H. megalops Kobayashi, 1934b; Hystricurus sp. 1; Jujuyaspis sinensis Zhou in Chen et al., 1980; Kainella euryrachis Kobayashi, 1953; Koraipsis spinus Kobayashi, 1934b; Leiostegium sp. 1; Pilekid sp. 1; Pliomerid sp. 1; Pliomerid sp. 2; Shumardia pellizzarii Kobayashi, 1934b; Trilobagnostus coreanicus (Kobayashi, 1960a); Yosimuraspis vulgaris Kobayashi, 1960a.

Yeongheung Formation (4 species): Asaphellus? sp. 1; Asaphid sp. 1; Asaphopsoidea maepoensis Choi, 1998b; Kayseraspis sp. cf. K. laticauda (Kobayashi, 1934b).

\subsection{Mungyeong Group}

Gurangni Formation (1 species): Redlichia nobilis Walcott, 1905. Undifferentiated carbonate formation (14 species): Amphoton microlops Kobayashi, 1942b; Amphoton spirula Kobayashi, 1942b; Anomocarella sp. 1; Dawsonia bunkeiensis (Kobayashi, 1943); Hedinaspis cf. regalis (Troedsson, 1937); Kootenia amanoi Kobayashi, 1961; Manchuriella sp. 1; Mungyongia tulipiformis Kobayashi, 1961; Palaeolenus aotii Kobayashi, 1961; Proceratopyge sp. 1; Pseudagnostus primus Kobayashi, 1935; Ptychoparia aff. impar Walcott, 1905; Ptychoparia sp. 1.; Redlichia cf. R. cynlindrica Chang, 1953.

\section{BIOSTRATIGRAPHY}

A series of studies on the trilobite faunas of the Taebaeksan Basin by Kobayashi (1934a, 1934b, 1935, 1960a, 1960b, 1961, 1962) formed the basis for establishing the biostratigraphic zonation of the Joseon Supergroup. The contrasting faunal contents of the Taebaek and Yeongwol groups resulted in two separate biostratigraphic schemes for the Cambrian-Ordovician successions of the Taebaeksan Basin (Kobayashi, 1966). The biostratigraphic zonation suggested by Kobayashi (1966) was widely employed without serious criticism, until trilobites of the Taebaek and Yeongwol groups were re-examined intensively during the last quarter century.

The revised biostratigraphy of the Taebaek and Yeongwol groups provides a more reliable correlation with the CambrianOrdovician biozones established elsewhere (cf. Geyer and Shergold, 2000; Peng et al., 2012). The refined biostratigraphy of 
the Joseon Supergroup has been comprehensively compiled by Choi et al. (2016) and hence is not fully described herein. Nonetheless, the lithostratigraphic and biostratigraphic summary of the Taebaek and Yeongwol groups is illustrated in Figures 3 and 4 .

In the Taebaek Group, trilobites have been reported from all but the lowermost Jangsan and Myeonsan formations. The trilobite biozones of the Taebaek Group have been intensively re-investigated during the last decade, except for the Myobong Formation. The trilobite faunal assemblages of the Taebaek Group are accommodated in 22 biozones: in ascending order, the Redlichia, Elrathia, Mapania (?), Bailiella, Crepicephalina, Amphoton, Jiulongshania, Neodrepanura, Liostracina simesi, Fenghuangella laevis, Prochuangia mansuyi, Chuangia, Kaolishania, Asioptychaspis subglobosa, Quadraticephalus, Eosaukia, Pseudokoldinioidia, Richardsonella, Asaphellus, Protopliomerops, Kayseraspis, and Dolerobasilicus zones (Fig. 3).

Trilobites of the Yeongwol Group have been intensively studied during the last two decades, which resulted in the recognition of 19 trilobite biozones: in ascending order, the Metagraulos sampoensis, Megagraulos semicircularis, Tonkinella, Ptychagnostus sinicus, Ptychagnostus atavus, Lejopyge armata, Glyptagnostus stolidotus, Glyptagnostus reticulatus, Proceratopyge tenuis, Hancrania brevilimbata, Eugonocare longifrons, Eochuangia hana, Agnostotes orientalis, Pseudoyuepingia asaphoides, Fatocephalus hunjiangensis, Yosimuraspis vulgaris, Kainella euryrachis, Shumardia pellizzarii, and Kayseraspis zones (Fig. 4).

The lower Paleozoic trilobites of the Mungyeong Group has not yet been re-evaluated. The biozones of the Mungyeong Group established by Kobayashi (1961) are, in ascending order, the Redlichia nobilis, Palaeolenus, Ptychoparia-Dawsonia, and Kootenia zones.

\section{PALEOGEOGRAPHY}

The remarkable trilobite faunal difference between the Yeongwol Group and the Taebaek Group during the early Paleozoic led Kobayashi (1967) to propose that the trilobites of the two group belonged to different faunal provinces: the Cambrian trilobites of the Taebaek Group belong to the Hwangho fauna which is characterized by the dominance of endemic trilobites inhabiting shallow marine environments, while those of the Yeongwol Group belong to the Jiangnan fauna which include many cosmopolitan and pelagic trilobites of deep-water environments. With the advent of the concept of plate tectonics, it was recognized that the eastern Asia had been divided into the Sino-Korean Craton (SKC) and the South China Craton (SCC) during the early Paleozoic (Burrett, 1973; Lin et al., 1985; Scotese and McKerrow, 1990). Accordingly, Cluzel et al. (1991) regarded the faunal contrast between the Taebaek Group and the Yeongwol Group as evidence for different paleogeographic affinity of the two groups: i.e., the Taebaek Group was part of the Sino-Korean Craton and the Yeongwol Group was part of the South China Craton. In contrast, Chough et al. (2000) ascribed the faunal difference between the Taebaek and Yeongwol groups to the difference in depositional environments in a contiguous marine setting, and regarded the Yeongwol Group as a deep-water setting on the Sino-Korean Craton. Choi and Kim (2006) discovered a Furongian trilobite species endemic to the Sino-Korean Craton, Changshania equalis Sun, 1935 from the Machari Formation of the Yeongwol Group (Fig. 5c), which corroborated the SinoKorean Craton affinity of the Yeongwol Group.

This section presents a new paleogeographic reconstruction of east Gondwana during the early Paleozoic, based on endemic trilobites and recent detrital zircon age spectra of the pertinent areas.

\subsection{Paleogeographic Implication of Cambrian-Ordo- vician Endemic Trilobites}

The paleogeographic position of the SKC in the early Paleozoic in conjunction with other major continental blocks of east Gondwana could be inferred from the occurrences of representative Cambrian-Ordovician endemic trilobites (Fig. 5) of five areas, including Taebaek, Yeongwol, Shandong (North China), Australia and Bhutan. The Cambrian trilobite Kaolishania occurs in Taebaek, Shandong, Australia, and Bhutan (Sun, 1924, 1935; Kobayashi, 1935; Zhang and Jell, 1987; Shergold et al., 2007; Hughes et al., 2011; Park et al., 2012); Hamashania in Taebaek, Shandong, and Australia (Zhang and Jell, 1987; Sohn and Choi, 2005, 2007; Shergold et al., 2007); and Changshania in Shandong and Yeongwol (Sun, 1924, 1935; Zhang and Jell, 1987; Choi and Kim, 2006; Choi et al., 2008). The Tremadocian endemic trilobites, Yosimuraspis and Koraipsis, have been reported from Taebaek, Yeongwol, Shandong, and Australia (Kobayashi, 1934b, 1960; Chang, 1966; Zhou and Zhang, 1985; Shergold, 1991; Kim and Choi, 2000a, b; Shergold et al., 2007). The distribution of these endemic trilobite taxa demonstrates close paleogeographic linkages of these areas during the early Paleozoic.

Early Paleozoic sedimentation also commenced at $\sim 520 \mathrm{Ma}$ in the Bonaparte and Arafura basins, northwestern Australia (Shergold et al., 1985, 2007; Metcalfe, 2013). The lowermost Tarrara Formation of the Bonaparte Basin is a succession of red micaceous quartz sandstone, green, red and brown shale and mudstone, and gray or red dolostone, and yields Redlichia along with hyoliths and inarticulate brachiopods. The lithology and trilobites of the Tarrara Formation are reminiscent of those of the Gurangni and Sambangsan formations of the Taebaeksan 

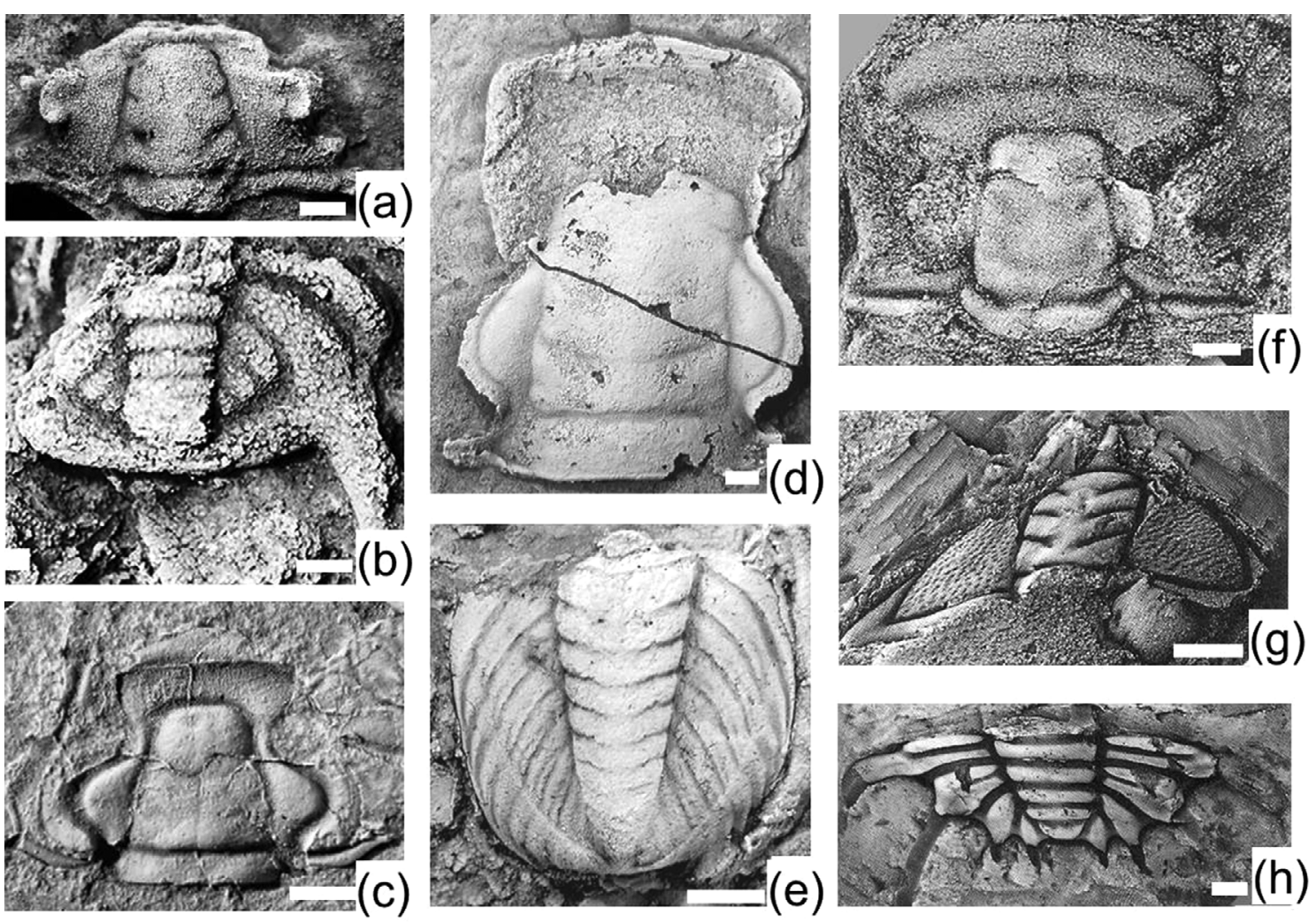

Fig. 5. Representative Cambrian-Ordovician endemic trilobite genera from east Gondwana. (a and b) Kaolishania granulosa Kobayashi, 1933 from the Kaolishania Zone of the Sesong Formation, Korea. (c) Changshania equalis Sun, 1935 from the Eochuangia hana Zone of the Machari Formation, Korea. (d and e) Hamashania pulchera Kobayashi, 1942 from the Quadraticephalus Zone of the Hwajeol Formation, Korea. (f) Yosimuraspis vulgaris Kobayashi, 1960 from the Yosimuraspis Zone of the Mungok Formation, Korea. ( $\mathrm{g}$ and h) Koraipsis spinus Kobayashi, 1934 from the Shumardia Zone of the Mungok Formation, Korea. Scale bars represent 2-mm-long.

Basin, Korea (Kobayashi, 1961) and the Mantou Formation of North China (Zhang and Jell, 1987). Some of endemic trilobites to the SKC, such as Kaolishania, Hamashania, Yosimuraspis, Koraipsis, were reported to occur in the Bonaparte Basin, northwestern Australia (Shergold et al., 2007). The co-occurrences of endemic trilobite taxa in the SKC and northwestern Australia strongly suggest that in the early Paleozoic the two regions were connected through contiguous shallow waters. The Taebaeksan Basin and most of the currently southern part of the SKC may have been occupied by an epeiric sea, facing to the core Gondwana.

A new paleogeographic configuration in Figure 6 was modified from previously known paleogeographic maps of Veevers (2004), Metcalfe (2006, 2013), and McKenzie et al. (2011), and accommodates the occurrences of the representative endemic trilobite taxa (Fig. 5). The deep-water setting with incipient oceanic ridges between the SKC and SCC follows the suggestion of Metcalfe (2006) and accord with the slope to basinal facies at the western margin of the Ordos Basin (Zhou et al., 1989). The area is known as the Helan trough or aulacogen in China (Sun et al., 1989; Lin et al., 1995; Yin and Nie, 1996; Chen et al., 2007). The early Paleozoic epeiric sea occupying the Taebaeksan Basin and much of the SKC was termed as the "Joseon Sea" (Choi, 2014), which was the site for deposition of the Joseon Supergroup of the Taebaeksan Basin and the coeval strata elsewhere in the SKC. In the early Paleozoic, epeiric seas including the Joseon Sea were aligned along the margin of east Gondwana (Fig. 6).

\subsection{Detrital Zircon Age Spectra and Provenance of Lower Paleozoic Sandstones in East Gondwana}

In order to elaborate the Early Paleozoic paleogeographic configuration in east Gondwana, the provenance data of sediments inferred from the detrital zircon age spectra of seven pertinent areas have been assembled for comparison (Fig. 7a): they are the Taebaek (Furongian Sesong Formation, McKenzie et al., 2011), Yeongwol (middle Cambrian Sambangsan Formation, Kim et al., 2013), Xian (middle Cambrian Mantou Formation, McKenzie et al., 2011), Inner Mongolia (middle Cambrian, Darby and Gehrels, 2006), northwestern Australia (Lower Ordovician Carranya Formation, Heines and Wingate, 2007), South China (Furongian, Wu et al., 2010), and Bhutan (Furongian Quartzite Formation, McKenzie et al., 2011). These detrital zircon age spectra of east Gondwana reveal interesting patterns. The age 

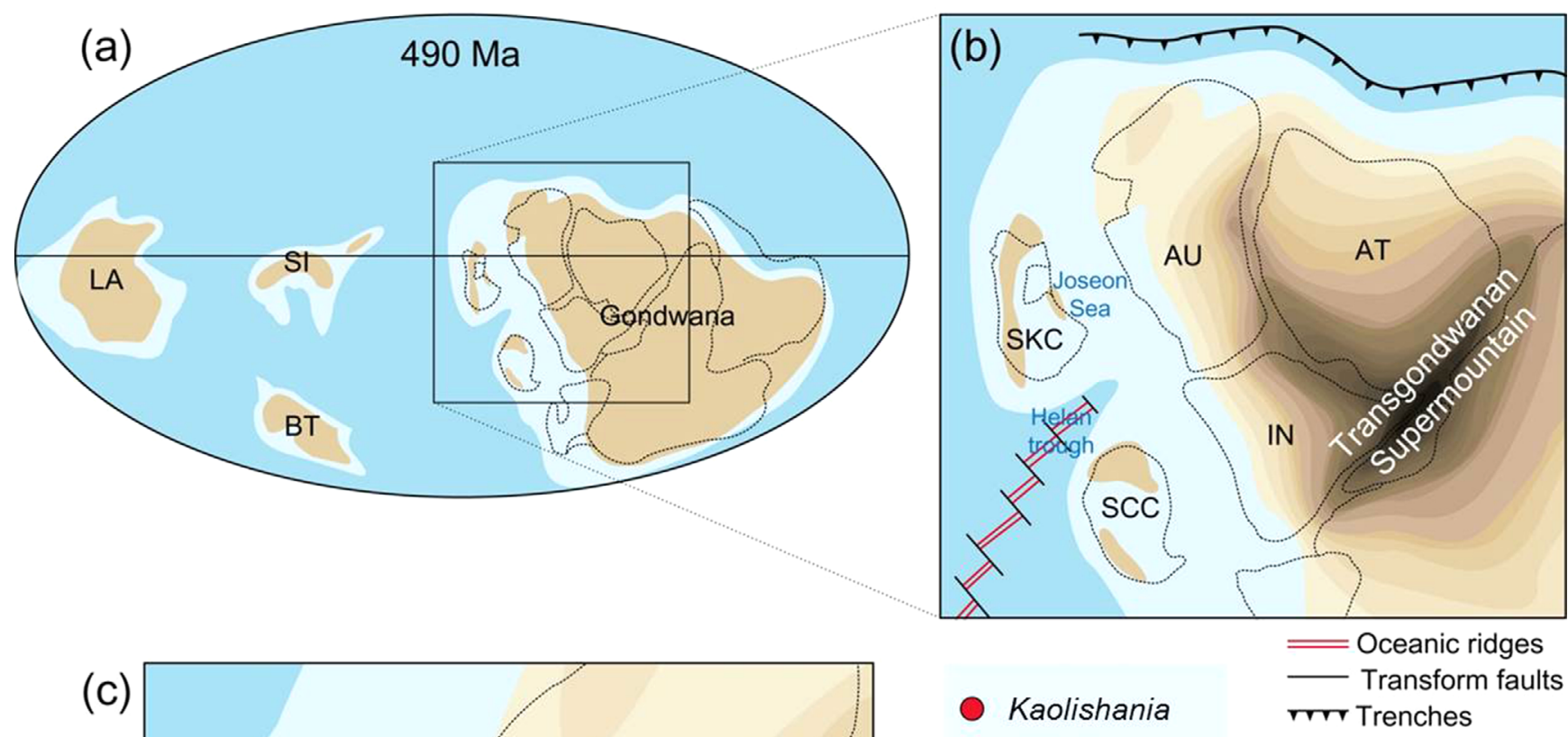

(c)

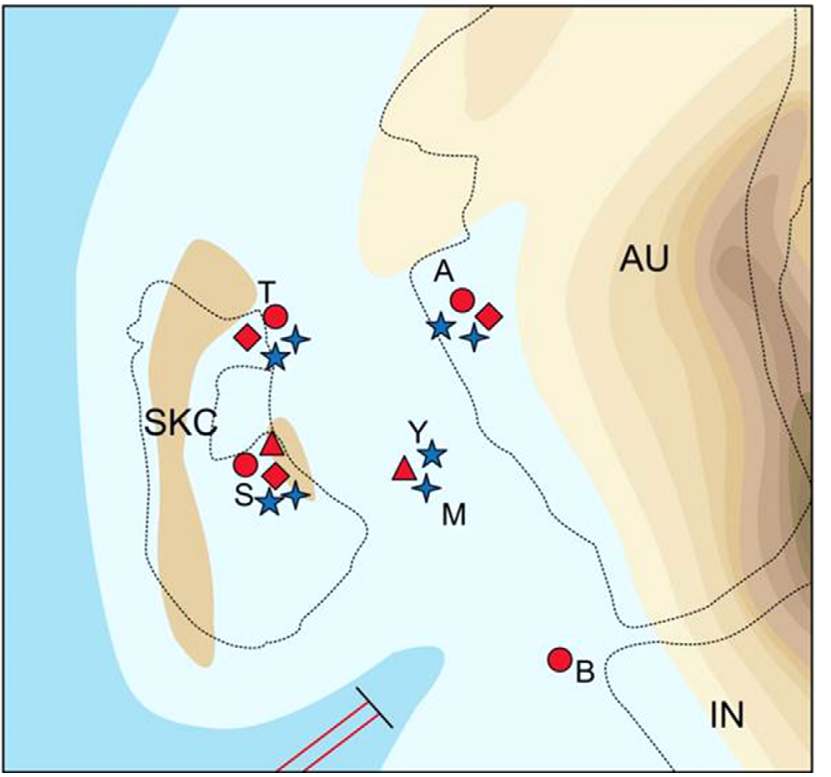

Kaolishania

Hamashania

$\Delta$ Changshania

\section{Yosimuraspis}

Koraipsis

A: Australia (Bonaparte Basin)

B: Bhutan

M: Mungyeong

$\mathrm{S}$ : Shandong

T: Taebaek

Y: Yeongwol

Fig. 6. Cambrian paleogeographic reconstruction at $490 \mathrm{Ma}$. (a) Global paleogeographic map, modified after Veevers (2004). (b) Close-up view of east Gondwana. Note that the Sino-Korean Craton was separated from Australia by the Joseon Sea and from the South China Craton by the Helan trough. (c) Occurrences of early Paleozoic endemic trilobites in the Joseon Sea. Kaolishania, Hamashania, and Changshania are the Cambrian trilobites, while Yosimuraspis and Koraipsis are the Ordovician trilobites. Abbreviations: AT - Antarctica, AU - Australia, BT - Baltica, IN - India, LA - Laurentia, SCC - South China Craton, SKC - Sino-Korean Craton, SI - Siberia. Modified from Choi (2014).

spectra of Inner Mongolia are unique in lacking zircon grains younger than $\sim 1.8 \mathrm{Ga}$ with a major age peak at $2.0-1.8 \mathrm{Ga}$ and minor Neoarchean age peaks, whereas those of other areas display a wide range of ages spanning mainly from Mesoproterozoic to early Paleozoic. This contrast may be attributable to the difference in paleogeographic settings: i.e., all the areas but Inner Mongolia were located within the Joseon Sea of east Gondwana (Fig. 7b) and thus sediments were largely derived from core Gondwana with little input from nearby land masses (e.g., SKC and SCC), whereas Inner Mongolia was located at the far side of the SKC away from the core Gondwana and hence the sediments were exclusively provided from the SKC itself. It is noteworthy that the age spectra of Yeongwol, Xian, and Bhutan are remarkably similar to each other (Fig. 7a), implying that the three areas must have shared provenances and have been in close proximity in the early Paleozoic. It is postulated that Yeongwol, Xian, and Bhutan received most of sediments from core Gondwana which was characterized by the presence of the Transgondwanan Supermountain (Squire et al., 2006) or East African-Antarctic Orogen (Jacobs and Thomas, 2004; Cawood and Buchan, 2007). The Transgondwanan Supermountain is estimated to have been a > 8000-km-long and > 1000-km-wide mountain chain which was formed by collision of east and west Gondwana during the period of 650-460 Ma (Squire et al., 2006). On the other hand, 

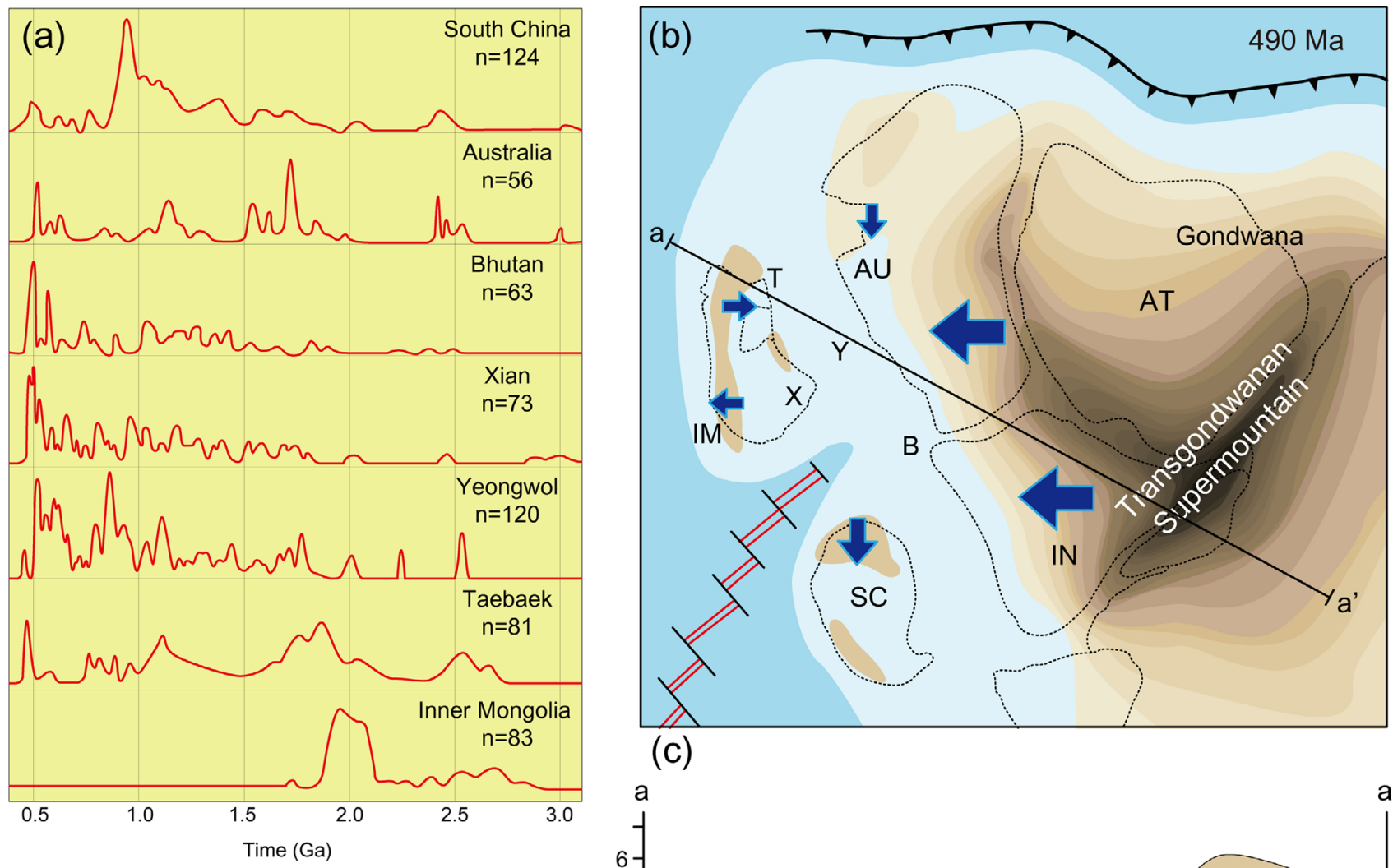

(c)

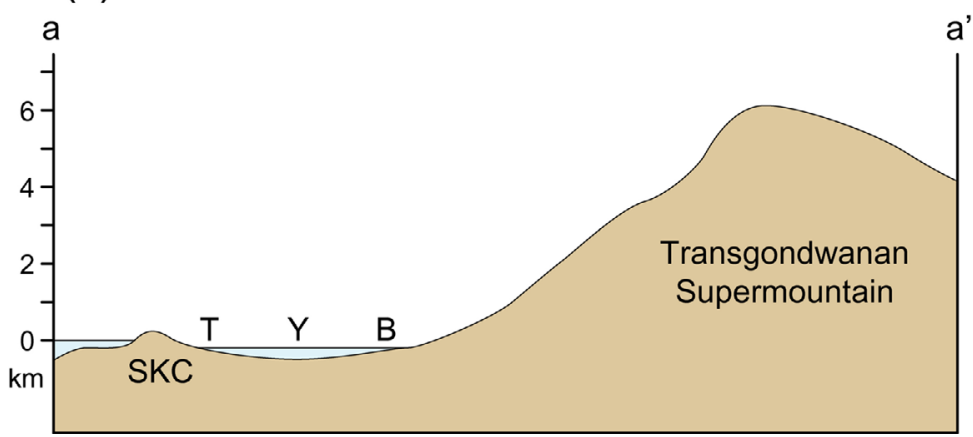

Fig. 7. Detrital zircon age spectra and provenance of the lower Paleozoic sedimentary rocks of east Gondwana. (a) Data for detrital zircon age spectra are obtained from the following sources: South China (upper Cambrian, Wu et al., 2010), Australia (Lower Ordovician Carranya Formation, Heines and Wingate, 2007), Bhutan (Furongian Quartzite Formation, McKenzie et al., 2011), Xian (middle Cambrian Mantou Formation, McKenzie et al., 2011), Yeongwol (middle Cambrian Sambangsan Formation, Kim et al., 2013), Taebaek (Furongian Sesong Formation, McKenzie et al., 2011), and Inner Mongolia (middle Cambrian, Darby and Gehrels, 2006). (b) Paleogeographic map of east Gondwana at 490 $\mathrm{Ma}$, demonstrating the relative contribution of sediment influx. Abbreviations are the same as those of Figure 8, but IM and $\mathrm{X}$ denote Inner Mongolia and Xian, respectively. (c) Topographic profile of a-a' in Figure 9b. Vertical exaggeration: approximately $\times 500$. Modified from Choi (2014).

Taebaek is distinct in displaying an intermediate pattern of age spectra between Inner Mongolia and Yeongwol/Xian/Bhutan. It is interpreted that Taebaek was located close to the onshore SKC ("T" in Figs. 7b and c) and hence the sediments were supplied from both the SKC and core Gondwana. The detrital zircon age spectra, trilobite faunal assemblages, and depositional settings enable to postulate that Taebaek and Yeongwol may have been placed far away from each other $(>1000 \mathrm{~km})$ in the early Paleozoic. The positioning of Yeongwol ("Y" in Figs. 9b and c) in the middle (or deepest part) of the Joseon Sea is in accordance with the depositional setting in a dysaerobic environment and abundant occurrence of pandemic agnostoid trilobites in the Machari Formation (Choi et al., 2004b) and the detrital zircon age spectra pattern of the Sambangsan Formation (Fig. 7a; Kim et al., 2013). Northwestern Australia (Canning Basin) and South China appear to have been influenced more strongly by local sources in having their own detrital zircon age spectra. With these detrital zircon age spectra of the pertinent areas the sediment influx patterns in the new paleogeographic configuration of east Gondwana can be reconstructed as in Figure $7 \mathrm{~b}$.

In summary, the early Paleozoic paleogeographic setting of the SKC can be reconstructed as an elongated island separated from the core Gondwana by an epeiric sea, the Joseon Sea, and from the SCC by deep water with incipient oceanic ridges, the Helan trough (Figs. $6 \mathrm{~b}$ and $7 \mathrm{~b}$ ). Predominance of fine-grained clastic sediments in the lower Paleozoic successions of the SKC 
(Meng et al., 1997; Kwon et al., 2006; Chough et al., 2010; Chen et al., 2012) indicates that the SKC was topographically low, hardly attaining up to several hundred meters high in maximum elevation in the early Paleozoic (Fig. 7c).

\section{ONTOGENY AND PHYLOGENY}

Researches on trilobite ontogeny have played an important role in understanding various aspects of trilobites (see Chatterton and Speyer, 1997). The most important contribution of trilobite ontogeny, however, comes from its usage for trilobite phylogeny (e.g., Whittington, 1957; Fortey, 2001). Although a caution is required for direct comparison of protaspid morphology of different trilobite lineages (Park and Choi, 2011c), protaspid morphology has long been regarded as holding implications for higher-level classification (Whittington, 1957). For examples, Fortey and Owens (1975) established the Order Proetida, and one of the main features of the order is the presence of preglabellar field in the protaspides (Fortey, 2001). Fortey and Chatterton (1988) regarded the presence of a bulbous, metamorphosisundergoing "asaphoid protaspis" as one of the synapomorphies for grouping the Order "Asaphida" (sensu Fortey and Chatterton, 1988; Fortey, 1990).

Elucidating the Cambrian roots of the post-Cambrian trilobites has remained one of the intractable problems in trilobite phylogeny (Fortey 2001; Whittington 2007), and the discovery of early growth stages of the Cambrian trilobites could be crucial in solving the issue. However, silicified trilobite faunas which would include the best specimens of early developmental stages are not common in the Cambrian strata around the world, and especially, those of the Furongian strata are extremely rare. In this regard, the silicified trilobite fauna from the Furongian strata of the Taebaeksan Basin is of particular importance, and the ontogenetic researches of some species have already played a key role in verifying the pre-existing hypothesis for trilobite phylogeny.

Ontogenetic research of Korean trilobites was first attempted by Choi and Lee (1993) who documented the ontogeny of Dolerobasilicus yokusensis (Kobayashi, 1934a) from the Jigunsan Formation of the Taebaek Group. During the next 15 years, ontogenetic research was mainly executed on the Cambrian trilobites from the Yeongwol Group. Subsequently from 2009, the focus of the ontogenetic research was shifted to the silicified sclerites dissolved out of the carbonates of the Taebaek Group.

\subsection{Ontogenetic Researches from the Yeongwol Group}

All of the trilobites of the Yeongwol Group used for ontogenetic research were from the Machari Formation, and those researches focused mainly on the shape change during development and its implications for the morphological evolution.

Lee and Choi (1999a) provided a description of the postembryonic cranidial development of the olenid trilobite, Olenus asiaticus Kobayashi, 1944, from the Glyptagnostus reticulatus Zone which indicates the base of the Furongian Series. This was the first ontogenetic research on the trilobites from the Yeongwol Group. They documented two stages of the protaspid phase and the subsequent cranidial development, and compared their morphology to the ontogeny of other species of Olenus.

Hwang et al. (2000) described the ontogeny of the olenid trilobite, Hancrania brevilimbata Kobayashi, 1962, from the Hancrania brevilimbata Zone of the Machari Formation, which is slightly younger than the Glyptagnostus reticulatus Zone, and discovered that the morphological features during development are similar to those of Olenus which might be closely related to Hancrania.

Hong et al. (2003a) collected trilobite sclerites composed of calcium phosphate, dissolved out of the limestone from the Lejopyge armata Zone (Guzhangian) in the lower part of the Machari Formation. The sclerites from the residue included the immature cranidia of the diceratocephalid trilobite, Cyclolorenzella sp.

Hwang and Choi (2005) provided a more detailed ontogenetic comparison of $O$. asiaticus and $H$. brevilimbata. On an assumption that Olenus asiaticus was an ancestral to Hancrania brevilimbata, they employed the concept of combined heterochnoric process for the morphological evolution within this lineage: i.e., the reduced preglabellar field in $H$. brevilimbata was attained by paedomorphosis, while the adaxially expanded glabella was a result of peramorphosis.

Choi et al. (2008) documented trilobites from the Eochuangia hana, Agnostotes orientalis, and Pseudoyuepingia asaphoides zones of the middle part of the Machari Formation. The material for the systematic description of the fauna includes immature cranidia of Metachangshania brachypyga Choi, Kim, and Lee, 2008, immature cranidia and pygidia of Haniwoides longus Kobayashi, 1935, and immature cranidia of Joshuaspis parvus Choi, Kim, and Lee, 2008, and the description of ontogenetic changes of each species were provided.

\subsection{Ontogenetic Researches from the Taebaek Group}

Although the specimens for the first ontogenetic research were preserved in the dark gray shale of the Jigunsan Formation, most of the recent ontogenetic researches on the trilobites from the Taebaek Group were based on the silicified sclerites preserved in the carbonate successions. They can be easily dissolved out by hydrochloric acid, and the liberated sclerites provide detailed 
morphological information throughout the ontogeny which is crucial for the ecology, evolution, and phylogeny of trilobites.

Choi and Lee (1993) documented the ontogeny of Dolerobasilicus yokusensis (Kobayashi, 1934a), from the late Middle Ordovician (Darriwillian) Jigunsan Formation. The protaspides of Dolerobasilicus were the first discovery of protaspis in Korea. They focused largely on the morphological change in cephalon during development. This study subsequently developed into a more detailed research on the recognition of bacculae in the Asaphinae (Lee and Choi, 1999b).

The subsequent ontogenetic researches on the trilobites from the Taebaek Group were all based on the silicified sclerites from the Guzhangian to Tremadocian carbonate successions. In a brief review written in Korean, Park and Choi (2012b) summarized the phylogenetic implications of Park and Choi (2009; 2010b; 2011a), which are also reviewed here.

Park and Choi (2009) documented the full post-embryonic development of the tsinaniid trilobite, Tsinania canens (Walcott, 1905), from the Asioptychaspis subglobosa Zone of the Hwajeol Formation, which is middle Furongian in age (Jiangshanian Stage). This was the first paper challenging the concept of the Order "Asaphida" (sensu Fortey and Chatterton 1988; Fortey 1990) which was grouped by the presence of a ventral median suture and the bulbous "asaphoid protaspis". Park and Choi
(2009) discovered that a ventral median suture had appeared also in the Tsinaniidae which belongs to the Order Corynexochiida. The ventral median suture of $T$. canens formed via reduction of a triangular rostral plate during development. This is contrasting to the evolutionary mode of ventral median suture formation proposed by Chatterton et al. (1994), which involves a reduction of an inverted triangular rostral plate. The sudden degeneration of the large pygidial spines within the early holaspid phase of Tsinania canens was interpreted to be related to a change in life mode from benthic crawling to infaunal.

Park and Choi (2010a) dealt with the post-protaspid ontogeny of the two diceratocephalid trilobites, Cyclolorenzella convexa (Resser and Endo in Endo and Resser, 1937) and Diceratocephalus cornutus (Endo in Endo and Resser, 1937), from the Neodrepanura Zone of the Sesong Formation, which is Guzhangian in age. The two genera had not been recognized as closely related, but the well-preserved silicified material from the Sesong Formation revealed that the two trilobites are almost identical except for the presence of a pair of large frontal horns in D. cornutus (Fig. 8). The occurrence of $C$. convexa immediately underlies that of D. cornutus, which likely indicates that the two trilobites are of a direct ancestor-descendant relationship. The post-protaspid ontogeny of the two trilobites demonstrates that the presence of frontal horns in D. cornutus was an evolutionary novelty which can be
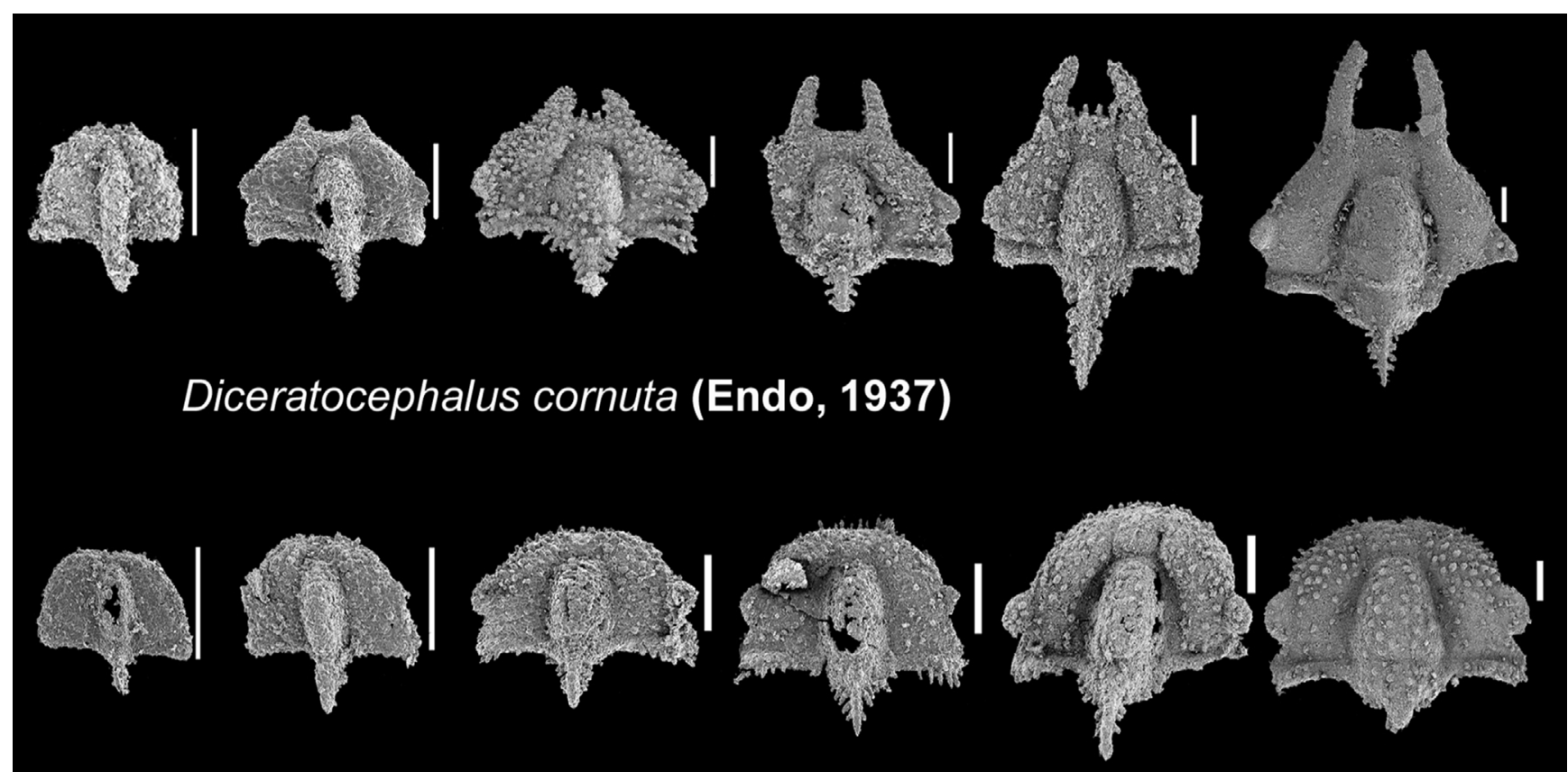

\section{Cyclolorenzella convexa (Resser \& Endo, 1937)}

Scale bars are $0.5 \mathrm{~mm}$ long

Fig. 8. Cranidial development of the two diceratocephalid trilobites, Diceratocephalus cornutus (Endo in Endo and Resser, 1937) (upper row) and Cyclolorenzella convexa (Resser and Endo in Endo and Resser, 1937) (lower row), from the Neodrepanura Zone of the Sesong Formation. Note that the morphologies of the two trilobites are almost identical except for the presence of a pair of frontal horns in D. cornutus (Modified from Park and Choi, 2010a). 
explained by a redeployment of the pre-existing regulatory gene.

Park and Choi (2010b) documented the ontogeny of the dikelocephaloid trilobite, Asioptychaspis subglobosa (Sun, 1924), from the same horizon of the Hwajeol Formation where the specimens of T. canens in Park and Choi (2009) occurred. This research was a sequel to Park and Choi (2009) in that it dealt with the concept of the Order "Asaphida" (sensu Fortey and Chatterton, 1988; Fortey, 1990). The Superfamily Dikelocephaloidea was considered as belonging to the Order "Asaphida", based on the presence of a ventral median suture. Dikelocephaloideans were also predicted to possess a bulbous "asaphoid protaspis" by Fortey and Chatterton (1988). However, the ontogeny of $A$. subglobosa revealed that the ventral median suture of this trilobite was formed by splitting a yoked free cheek, which is contrasting to the evolutionary mode of ventral median suture of the "Asaphida," proposed by Chatterton et al. (1994). In addition, the protaspid morphology of $A$. subglobosa is not of bulbous "asaphoid protaspis", but is of an adult-like shape, corroborating that the Superfamily Dikelocephaoidea is not closely related to other members of the Order "Asaphida."

Ontogeny of the remopleuridioid trilobite, Haniwa quadrata Kobayashi, 1933 by Park and Choi (2011a) was the third paper dealing with the concept of the Order "Asaphida" (sensu Fortey and Chatterton, 1988; Fortey, 1990). The Superfamily Remopleuridioidea was also regarded as a member of the Order "Asaphida" by Fortey and Chatterton (1988). The specimens of $H$. quadrata were collected also from the same horizon of the
Hwajeol Formation from which the specimens of T. canens and A. subglobosa occurred. Since this Furongian remopleuridioid trilobite had a rather directly-developing protaspis and a yokedfree cheek, the highly bulbous commutavi protaspis and the ventral median suture of the Ordovician remopleuridioid trilobites noted by Fortey and Chatterton (1988) must have been a result of independent evolution within the remopleuridioidean lineage. The ontogenetic researches on the three Furongian trilobites from the Asioptychaspis subglobosa Zone of the Hwajeol Formation revealed that a ventral median suture and an "asaphoid protaspis"like morphology could have evolved multiple times within different lineages. Subsequently, Park et al. (2014) disproved the "Asaphida" membership of the Superfamily Trinucleoidea. As a result, the current concept of the Asaphida only includes five families: Ceratopygidae, Asaphidae, Taihunshaniidae, Nileidae, and Cyclopygidae (Fig. 9).

Documenting the faunal changes around the base of the Furongian Series of the Taebaek Group, Park and Choi (2011b) described the ontogeny of the menomoniid trilobite, Alataspis sesongensis Park and Choi, 2011b, from the Sesong Formation. The protaspid morphology of this basal Furongian menomoniid was comparable to that of the late middle Cambrian menomoniid, Bolaspidella housensis (Walcott, 1886), described by Lee and Chatterton (2005).

Park et al. (2012) reported the trilobites of the Kaolishania fauna from the upper part of the Sesong Formation, and illustrated immature specimens of Shirakiella elongata Kobayashi, 1935,
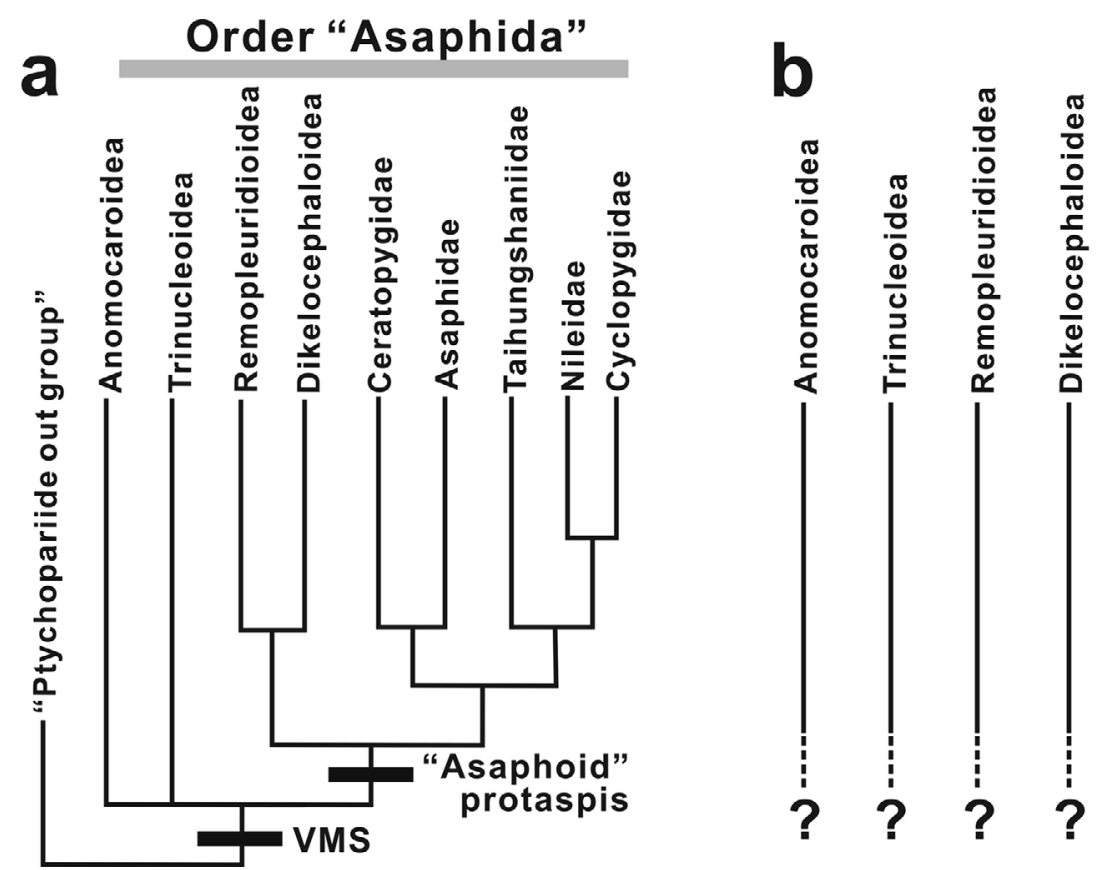

\section{Order Asaphida}

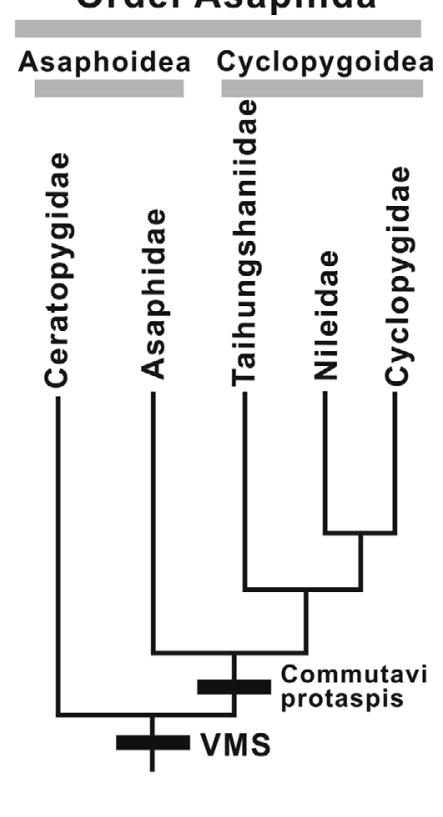

Fig. 9. (a) a tree describing the phylogenetic relationships within the traditional Order "Asaphida", based on Fortey and Chatterton (1988, text-fig. 1) and Chatterton et al. (1994, fig. 13). VMS represents the ventral median suture. (b) a diagrammatic tree describing the current status of the Order Asaphida, modified from Park and Choi (2012b) and Park et al. (2016). 
Pagodia sp. cf. P. spina Qian, 1994, Kaolishania granulosa Kobayashi, 1933, Gumunsoia triangularis Park, Sohn, and Choi, 2012, and Lingyuanaspis sp. The immature pygidial morphology with an upturned lateral border-like structure in K. granulosa and G. triangularis was similar to that of T. canens, which indicates close phylogenetic relationships between these corynexochiide trilobites.

The ontogeny of another ptychaspidid trilobite, Quadraticephalus elongatus Kobayashi, 1935, from the Quadraticephalus Zone of the Hwajeol Formation was studied by Kihm et al. (2013). The occurrence of Q. elongatus just overlying that of Asioptychaspis subglobosa, and the similar mature and immature morphology indicate a close phylogenetic relationship of the two ptychaspidid species. The developmental feature of $Q$. elongatus is generally similar to A. subglobosa except that Q. elongatus has a less convex cranidium throughout the ontogeny. Interestingly, a single protaspid stage was recognized for Q. elongatus, while the probable ancestor, A. subglobosa, had two stages for protaspid phase. The size of the protaspides of $Q$. elongatus is more-or-less similar to the size of the early stage protaspides of $A$. subglobosa (Kihm et al., 2013, fig. 9). Kihm et al. (2013) ascribed this to an earlier appearance of the first articulation between cranidium and trunk in Q. elongatus. Such difference in the appearance timing of the first articulation was discussed by Park and Choi (2011c). Kihm et al. (2013) also reconstructed a trunk segmentation schedule diagram of Q. elongatus, and discovered that the pygidial development of $Q$. elongatus had undergone an accumulation phase, an equilibrium phase, and a depletion phase, successively.

Park et al. (2013) described the fauna of the Jiulongshania Zone (Guzhangian Stage) at the lowermost part of the Sesong Formation, and illustrated the immature specimens of Bergeronites ketteleri (Monke, 1903), Stephanocare richthofeni Monke, 1903, Teinistion lansi Monke, 1903, Teinistion sp., Hebeia sp., Jiulongshania longispina (Wittke and Zhu in Zhu and Wittke, 1989), and Jiulongshania regularis (Walcott, 1906).

Park and Kihm (2015a) described the trilobite fauna of the Asioptychaspis subglobosa Zone of the Hwajeol Formation, and include a brief description of the immature cranidia of the saukiid trilobite, Caznaia coreaensis Park and Kihm, 2015a. They did not provide any implication from the partial ontogeny of $C$. coreaensis, but the smallest cranidium (Park and Kihm, 2015a, fig. 7a) is reminiscent of the smallest immature cranidia of $A$. subglobosa and $Q$. elongatus, which might reflect the membership of the Superfamily Dikelocephaloidea.

The first ontogenetic research on the Tremadocian trilobites of the Taebaek Group was provided by Park and Kihm (2015b) who described the ontogeny of the remopleuridioid trilobite, Apatokephalus latilimbatus Peng, 1990 from the upper part of the Dongjeom Formation. Park and Kihm (2015b) discovered that the protaspis of this trilobite represents the initial stage of the evolution of a commutavi protaspis in the remopleuridioidean lineage. Interestingly, the commutavi protaspis of a bulbous morphology was apparently intercalated into the ancestral direct development, probably as a specialized stage for a better dispersal. In the younger remopleuridioidean trilobites, the bulbous morphology became extended into the earlier protaspid stage and even into the subsequent earliest meraspid phase (see Park and Kihm, 2015b, fig. 10). In addition, they replaced the terminology, "asaphoid protaspis," as the 'commutavi protaspis' for the metamorphosis-undergoing, bulbous protaspis; the new terminology is free from incorrect phylogenetic connotation.

Park (in press) documented the ontogeny of the two cooccurring middle Furongian (Jiangshanian Stage) shumardiid trilobites from the Asioptychaspis subglobosa Zone of the Hwajeol Formation. The ontogenetic research on the Tremadocian shumardiid, Shumardia (Conophrys) salopiensis (Callaway, 1877), by Stubblefield (1926) was monumental in that it revealed the trunk segmentation process in trilobites for the first time. However, the rather flat, adult-like protaspid morphology described by Stubblefield (1926) remained contentious, because Waisfeld et al. (2001) discovered commutavi protaspides for Middle Ordovician shumardiids. With the commutavi protaspides of the two middle Furongian shumardiids, Park (in press) could confirm that shumardiids indeed had commutavi protaspis quite early in evolution of the lineage, disproving the adult-like protaspid morphology described by Stubblefield (1926).

\section{FUTURE PERSPECTIVES OF TRILOBITE RESEARCH IN KOREA}

Despite the active researches on various aspects during the last quarter century, it should be emphasized that there remains much more to be studied for Korean trilobites.

In the Taebaek Group, the discovery of silicified trilobite fauna from the carbonate strata may open a new era for taxonomic, biostratigraphic, and ontogenetic researches. The carbonaterich middle Cambrian Daegi Formation and the Tremadocian to Floian Dumugol Formation contain numerous silicified trilobite sclerites (Fig. 10) which are yet to be studied. The carbonates of the upper part of the Dongjeom Formation also contains silicified trilobites (e.g., Park and Kihm, 2015b) which are expected to be useful for establishing a new biozone in this interval. Although not as fossiliferous as the older strata of the Taebaek Group, the calcareous intervals of the Darriwilian Jigunsan and Duwibong formations also produce silicified trilobite sclerites. Moreover, many of the fossiliferous intervals of the Sesong and Hwajeol formations still remain unstudied on the basis of dissolved-out sclerites. For examples, the Neodrepanura Zone of the Sesong Formation contains faunas of various late Guzhangian trilobites 


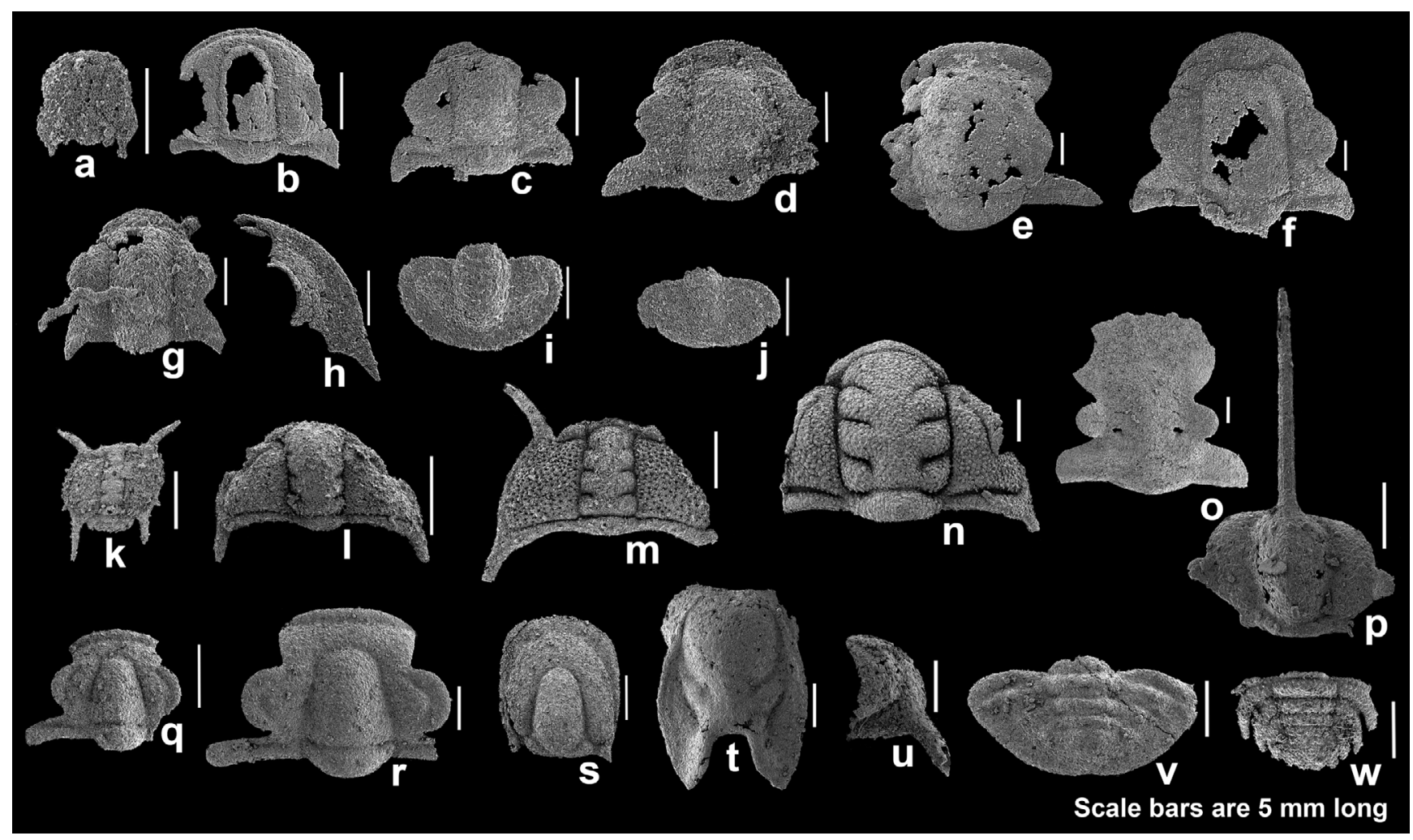

Fig. 10. Indeterminate silicified trilobite sclerites from the middle Cambrian (Cambrian Series 3) Daegi Formation and the Tremadocian to Floian Dumugol Formation: (a-j) trilobite sclerites from the Daegi Formation; (a) KOPRIF1362, a protaspis, (b-g) KOPRIF1363-1368, cranidia, (h) KOPRIF1369, a free cheek, (I and j) KOPRIF1370-1371, pygidia; (k-w) trilobite sclerites from the Dumugol Formation; (k) KOPRIF1372, a protaspis, (I-s) KOPRIF1373-1380, cranidia, (t) KOPRIF1381, a hypostome, (u) KOPRIF1382, a free cheek, (v-w) KOPRIF1383-1384, pygidia. All materials are housed in Korea Polar Research Institute.

which are similar to the diverse faunas of the Neodrepanura Zone of North China (see Zhang and Jell, 1987). Of them, the ontogeny of only two diceratocephalid trilobites has been provided (Park and Choi, 2010a) and a complete faunal description is yet to be done. The Hwajeol Formation contains well-preserved silicified trilobite sclerites, and the dissolved-out silicified sclerites of only the lowermost biozone, the Asioptychaspis subglobosa Zone, have been described. The dissolved-out specimens of the overlying interval including the Quadraticephalus Zone of the Hwajeol Formation (see Sohn and Choi, 2007) have a great potential for the taxonomic, biostratigraphic, and ontogenetic researches. The problem of elucidating the trilobite phylogeny is likely dependent upon the understanding of the middle Cambrian (Cambrian Series 3) and the Furongian trilobite phylogeny. The future ontogenetic research on the trilobites from the middle Cambrian (Cambrian Series 3) and the Furongian strata of the Taebaek Group, therefore, could significantly contribute to elucidating the muddled trilobite phylogeny. More challenging task in the Taebaek Group would be revising the trilobites of the Myobong Formation. Of the four trilobite species of this formation, taxonomy of the two trilobites, Elrathia taikiensis Kobayashi, 1935 and Mapania beihoensis Kobayashi, 1935, which also forms the basis for the Elathia and Mapania (?) biozones, are rather problematic. However, no trilobite has been discovered during the past quarter century from this less fossiliferous, siliciclastic formation, and thus the biostratigraphy of this formation remains rather incomplete.

In the Yeongwol Group, the remaining biostratigraphic gaps could be filled in the future. In the lower part of the Machari Formation, the fauna from the two recently-established biozones, the Ptychagnostus sinicus and Ptychagnostus atavus zones, awaits a formal documentation. The relatively less-known Guzhangian interval could be more studied, as well. In the upper part of the Machari Formation, the interval above the Pseudoyuepingia asaphoides Zone remains to be studied for taxonomy and biostratigraphy.

The taxonomic and biostratigraphic revision of the trilobites of the Mungyeong Group has been a long-standing task since Kobayashi (1961). The relatively diverse fauna of the undifferentiated carbonate formation includes some species not known from the Taebaek and Yeongwol groups, such as Dawsonia bunkeiensis (Kobayashi, 1943) and Palaeolenus aotii Kobayashi, 1961, and thus restudy of this fauna could provide further useful information on the paleogeographic position of the Mungyeong area, relative to Taebaek and Yeongwol areas. 


\section{ACKNOWLEDGMENTS}

We are grateful to D.C. Lee and an anonymous referee for their constructive reviews. This study was supported by a grant from the National Research Foundation of Korea (Grant No. NRF-2014R1A1A2002851) to DKC, and TYSP was financially supported by a KOPRI project (PE16380).

\section{REFERENCES}

Angelin, N.P., 1851, Palaeontologia Svecica, Pars I: Iconographia Crustaceorum Formationis Transitionis, Fascicule I. Lund, 96 p.

Belt, T., 1867, On some new trilobites from the Upper Cambrian rocks of north Wales. Geological Magazine, 4, 294-295.

Burrett, C., 1973, Ordovician biogeography and continental drift. Palaeogeography, Palaeoclimatolgy, Palaeoecology, 13, 161-201.

Callaway, C., 1877, On a new area of Upper Cambrian rocks in South Shropshire, with a description of a new fauna. Quarterly Journal of the Geological Society of London, 33, 652-672.

Cawood, P.A. and Buchan, C., 2007, Linking accretionary orogenesis with supercontinent assembly. Earth-Science Reviews, 82, 217-256.

Chang, W.T., 1953, Some Lower Cambrian trilobites from western Hupeh. Acta Palaeontologica Sinica, 1, 121-149.

Chang, W.T., 1966, A few Lower Ordovician trilobites from eastern Shansi. Acta Palaeontologica Sinica, 14, 1-8.

Chatterton, B.D.E. and Speyer, S.E., 1997, Ontogeny. In: Kaesler, R.L. (ed.), Treatise on Invertebrate Paleontology. Part O (revised), Arthropoda 1. Trilobita 1. Geological Society of America and University of Kansas Press. Boulder, Colorado and Lawrence, p. 313330.

Chatterton, B.D.E., Speyer, S.E., Hung, A.S., and Fortey, R.A., 1994, Ontogeny and relationships of Trinucleoidea (Trilobita). Journal of Paleontology, 68, 523-540.

Chen, J.-Y., Zhou, Z.-Y., Zou, X.-P., Lin, Y.-K., Yang, X.-C., Wang, Q.-C., Qi, J.-K., Wang, Q.-Z., and Lu, X.-L., 1980, Ordovician sediments and faunas in the Taihang Mountains, North China. Memoirs of Nanjing Institute of Geology and Palaeontology, Academia Sinica, 16, 111-148. (in Chinese with English abstract)

Chen, J.-Y., Qian, Y.-Y., Lin, Y.-K., Zhang, J.-M., Wang, Z.-H., Yin, L.M., and Erdtmann, B.D., 1985, Study on Cambrian-Ordovician boundary strata and its biotas in Dayangcha, Hunjiang, Jilin, China. China Prospect Publishing House, Beijing, 138 p.

Chen, M., Ning, N., Hu, G.Y., and Li, J., 2007, Characteristics of hydrocarbon sources and controlling factors of their formation in Pingliang Formation, West Ordos Basin. Chinese Science Bulletin, 52, 103-112.

Chen, J., Chough, S.K., Lee, J.-H., and Han, Z., 2012, Sequence stratigraphic comparison of the upper Cambrian Series 3 to Furongian succession between the Shandong region, Chin and the Taebaek area, Korea: high variability of bounding surfaces in an epeiric platform. Geosciences Journal, 16, 357-380.

Chien, Y.-Y., 1961, Cambrian trilobites from Sandu and Duyun, southern Kweichow. Acta Palaeontologica Sinica, 9, 91-129. (in Chinese)

Cho, D.-L., Lee, S.R., Koh, H.J., Park, J.-B., Armstrong, R., and Choi,
D.K., 2014, Late Ordovician volcanism in Korea constrains the timing for breakup of Sino-Korean Craton from Gondwana. Journal of Asian Earth Sciences, 96, 279-286.

Choi, D.K., 1998a, The Yongwol Group (Cambrian-Ordovician) redefined - a proposal for the stratigraphic nomenclature of the Choson Supergroup. Geosciences Journal, 2, 220-234.

Choi, D.K., 1998b, An Early Ordovician trilobite faunule from the Choson Supergroup, Maepo, Tanyang area, Korea. Geosciences Journal, 2, 235-242.

Choi, D.K., 2007, Trilobite research in South Korea during the $20^{\text {th }}$ Century. New York State Museum Bulletin, 507, 81-95.

Choi, D.K., 2014, Geology and Tectonic Evolution of the Korean Peninsula. Seoul National University Press, Seoul, 277 p. (in Korean with English summary)

Choi, D.K. and Chough, S.K., 2005, The Cambrian-Ordovician stratigraphy of the Taebaeksan Basin, Korea: a review. Geosciences Journal, 9, 187-214.

Choi, D.K. and Kim, E.Y., 2006, Occurrence of Changshania (Trilobita, Cambrian) in the Taebaeksan Basin, Korea and its stratigraphic and palaeogeographic significance. Palaeogeography, Palaeoclimatology, Palaeoecology, 242, 343-354.

Choi, D.K. and Lee, D.C., 1993, Ontogeny and cephalic structures of asaphid trilobite Dolerobasilicus from Korea. Journal of Geological Society of Korea, 29, 73-83.

Choi, D.K., Kim, D.H., and Sohn, J.W., 2001, Ordovician trilobite faunas and depositional history of the Taebaeksan Basin, Korea implications for palaeogeography. Alcheringa, 25, 53-68.

Choi, D.K., Chough, S.K., Kwon, I.K., Lee, S.-B., Woo, J., Kang, I., Lee, H.S., Lee, S.M., Sohn, J.W., Shinn, Y.J., and Lee, D.-J., 2004a, Taebaek Group (Cambrian-Ordovician) in the Seokgaejae section, Taebaeksan Basin: a refined lower Paleozoic stratigraphy in Korea. Geosciences Journal, 8, 125-151.

Choi, D.K., Lee, J.G., and Sheen, B.C., 2004b, Upper Cambrian agnostoid trilobites from the Machari Formation, Yongwol, Korea. Geobios, 37, 159-189.

Choi, D.K., Kim, E.-Y., and Lee, J.G., 2008, Upper Cambrian polymerid trilobites from the Machari Formation, Yongwol, Korea. Geobios, 41, 183-204.

Choi, D.K., Lee, J.G., Lee, S.-B., Park, T.-Y.S., and Hong, P.S., 2016, Trilobite biostratigraphy of the lower Paleozoic (Cambrian-Ordovician) Joseon Supergroup, Taebaeksan Basin, Korea. Acta Geologica Sinica, 90, 1801-1824.

Chough, S.K., Kwon, S.-T., Ree, J.-H., and Choi, D.K., 2000, Tectonic and sedimentary evolution of the Korean peninsula - a review and new view. Earth-Science Reviews, 52, 175-235.

Chough, S.K., Lee, H.S., Woo, J., Chen, J. Choi, D.K., Lee, S.-B., Kang, I.S., Park, T.-Y., and Han, Z., 2010, Cambrian stratigraphy of the North China Platform: revisiting principal sections in Shandong Province, China. Geosciences Journal, 14, 235-268.

Cluzel, D., 1991, The Ogcheon belt (Republic of Korea): tectonics and geodynamics of a polycyclic intraplate domain. Journal of the Geological Society of Korea, 27, 515-519.

Dames, W., 1883, Kambrische Trilobiten von Liautung. In: Richthofen, F.F. (ed.), China: Ergebnisse Eigener Reisen und Darauf Gegründeter Studien, Volume 4. Palaeontology. Dietrich Reimer, Berlin, p. 3-33. Darby, B.J. and Gehrels, G.E., 2006, Detrital zircon reference for the 
North China block. Journal of Asian Earth Sciences, 26, 637-648.

Dong, Y., Zhang, G., Neubauer, F., Liu, X., Genser, J., and Hauzenberger, C., 2011, Tectonic evolution of the Qinling orogeny, China: Review and synthesis. Journal of Asian Earth Sciences, 41, 213-237.

Duan, J., An, S., and Zhao, D., 1986, Cambrian-Ordovician boundary and its interval biotas, southern Jilin, northeast China. Journal of Changchun College of Geology, Special Issue of Stratigraphy and Palaeontology, 1-135.

Endo, R., 1944, Restudies on the Cambrian formations and fossils in Southern Manchoukuo. Bulletin of Central National Museum of Manchoukuo, 7, 1-100. (in Japanese)

Endo, R. and Resser, C.E., 1937, The Sinian and Cambrian formations and fossils of southern Manchoukuo. Manchurian Science Museum Bulletin, 1, 1-474.

Ergaliev, G.K., 1980, Trilobites of the Middle and Upper Cambrian of the Malyi Karatau. Akademiya Nauk Kazakhskoy SSR, Institut Geologicheskikh Nauk, 1-211. (in Russian)

Fortey, R.A., 1990, Ontogeny, hypostome attachment and trilobite classification. Palaeontology, 33, 529-576.

Fortey, R.A., 2001, Trilobite systematics: the last 75 years. Journal of Paleontology, 75, 1141-1151.

Fortey, R.A. and Chatterton, B.D.E., 1988, Classification of the trilobite suborder Asaphina. Palaeontology, 31, 165-222.

Fortey, R.A. and Owens, R.M., 1975, Proetida - a new order of trilobites. Fossils and Strata, 4, 227-239.

Geyer, G. and Shergold, J.H., 2000, The quest for internationally recognized divisions of Cambrian time. Episodes, 23, 188-195.

Hall, J., 1863, Preliminary notice of the fauna of the Potsdam Sandstone, with remarks upon the previously known species of fossils and description of some new ones, from the sandstone of the Upper Mississippi Valley. $16^{\text {th }}$ Annual Report of the Regents of the University of New York on the condition of the State Cabinet of Natural History, p. 119-222.

Heines, P.W. and Wingate, M.T.D., 2007, Contrasting depositional histories, detrital zircon provenance and hydrocarbon systems: did the Larapintine Seaway link the Canning and Amadeus basins during the Ordovician. Proceedings of the Central Australian Basins Symposium (CABS), Alice Springs, Aug. 16-18, Special Publication, 2, p. 36-51.

Hong, P.S. and Choi, D.K., 2015, Cambrian Series 3 agnostoid trilobites Ptychagnostus sinicus and Ptychagnostus atavus from the Machari Formation, Yeongwol Group, Taebaeksan Basin, Korea. Journal of Paleontology, 89, 377-384.

Hong, P.S., Lee, J.G., and Choi, D.K., 2003a, Trilobites from the Lejopyge armata Zone (upper Middle Cambrian) of the Machari Formation, Yongwol Group, Korea. Journal of Paleontology, 77, 895-907.

Hong, P.S., Lee, J.G., and Choi, D.K., 2003b, The Late Cambrian trilobite Irvingella from the Machari Formation, Korea - evolution and correlation. Special Papers in Palaeontology, 70, 175-196.

Hughes, N.C., Myrow, P.M., McKenzie, N.R., Harper, D.A.T., Bhargava, O.N., Tangri, S.K., Ghalley, K.S., and Fanning, C.M., 2011, Cambrian rocks and faunas of the Black Mountain Klippe, Bhutan. Geological Magazine, 148, 351-379.

Hwang, H.-A. and Choi, D.K., 2005, Heterochrony of the Late Cambrian olenid trilobites from the Machari Formation, Yeongwol, Korea: implications for biostratigraphy and intercontinental cor- relation. Geosciences Journal, 9, 215-222.

Hwang, H.-A., Lee, J.G., and Choi, D.K., 2000, Ontogeny of the late Cambrian trilobite Hancrania brevilimbata Kobayashi, 1962 from the Machari Formation, Yongwol, Korea. Journal of Paleontological Society of Korea, 16, 57-66.

Jacobs, J. and Thomas, R.J., 2004, Himalayan-type indenter-escape tectonics model for the southern part of the late Neoproterozoic-early Palaeozoic East African-Antarctic orogen. Geology, 32, 721-724.

Jago, J.B. and Cooper R.A., 2005, A Glyptagnostus stolidotus trilobite fauna from the Cambrian of northern Victoria Land, Antarctica. New Zealand Journal of Geology and Geophysics, 48, 661-681.

Kihm, J.-H., Park, T.-Y., and Choi, D.K, 2013, Ontogeny of the ptychaspidid trilobite Quadraticephalus elongatus Kobayashi, 1935 from the Furongian (late Cambrian) Hwajeol Formation, Korea. Journal of Paleontology, 87, 379-390.

Kim, D.H. and Choi, D.K., 2000a, Jujuyaspis and associated trilobites from the Mungok Formation (Lower Ordovician), Yongwol, Korea. Journal of Paleontology, 74, 1031-1042.

Kim, D.H. and Choi, D.K., 2000b, Lithostratigraphy and biostratigraphy of the Mungok Formation (Lower Ordovician), Yongwol, Korea. Geosciences Journal, 4, 301-311.

Kim, H.S., Hwang, M.-K., Ree, J.-H., and Yi, K., 2013, Tectonic linkage between the Korean Peninsula and mainland Asia in the Cambrian: Insights from U-Pb dating of detrital zircon. Earth and Planetary Science Letters, 368, 204-218.

Kobayashi, T., 1931, Studies on the stratigraphy and palaeontology of the Cambro-Ordovician formation of Hua-lie-chai and Niu-hsintai, South Manchuria. Japanese Journal of Geology and Geography, 8, 131-189.

Kobayashi, T., 1933, Upper Cambrian of the Wuhutsui Basin, Liaotung, with special reference to the limit of the Chaumitian (or Upper Cambrian) of eastern Asia, and its subdivision. Japanese Journal of Geology and Geography, 11, 55-155.

Kobayashi, T., 1934a, The Cambro-Ordovician formations and faunas of South Chosen, Palaeontology, Part I, Middle Ordovician faunas. Journal of the Faculty of Science, Imperial University of Tokyo, Section II, 3, 329-519.

Kobayashi, T., 1934b, The Cambro-Ordovician formations and faunas of South Chosen, Palaeontology, Part II, Lower Ordovician faunas. Journal of the Faculty of Science, Imperial University of Tokyo, Section II, 3, 521-585.

Kobayashi, T., 1935, The Cambro-Ordovician formations and faunas of South Chosen, Palaeontology, Part III, Cambrian faunas of South Chosen with a special study on the Cambrian genera and families. Journal of the Faculty of Science, Imperial University of Tokyo, Section II, 4, 49-344.

Kobayashi, T., 1936, Three contributions to the Cambro-Ordovician fauna. Japanese Journal of Geology and Geography, 13, 163-184.

Kobayashi, T., 1942a, Two new trilobite genera, Hamashania and Kirkella. Journal of Geological Society of Japan, 49, 37-40.

Kobayashi, T., 1942b, Studies on the Cambrian trilobite genera and families (IV). Japanese Journal of Geology and Geography, 18, 197-212.

Kobayashi, T., 1943, Brief notes on the eodiscids I, their classification with a description of a new species and a new variety. Proceedings of the Imperial Academy, Tokyo, 19, 37-42. 
Kobayashi, T., 1944, The discovery of Olenus in South Chosen. Proceedings of the Imperial Academy of Tokyo, 20, 227-233.

Kobayashi, T., 1953, On the Kainellidae. Japanese Journal of Geology and Geography, 23, 37-61.

Kobayashi, T., 1960a, The Cambro-Ordovician formations and faunas of South Korea, Part VI, Paleontology V. Journal of the Faculty of Science, University of Tokyo, Section II, 12, 217-275.

Kobayashi, T., 1960b, The Cambro-Ordovician formations and faunas of South Korea, Part VII, Paleontology VI. Journal of the Faculty of Science, University of Tokyo, Section II, 12, 329-420.

Kobayashi, T., 1961, The Cambro-Ordovician formations and faunas of South Korea, Part VIII, Paleontology VII, Cambrian faunas of the Mun'gyong (Bunkei) District and the Samposan Formation of the Yŏngwŏl (Neietsu) District. Journal of the Faculty of Science, University of Tokyo, Section II, 13, 181-241.

Kobayashi, T., 1962, The Cambro-Ordovician formations and faunas of South Korea, Part IX, Paleontology VIII, The Machari fauna. Journal of the Faculty of Science, University of Tokyo, Section II, $14,1-152$.

Kobayashi, T., 1966, The Cambro-Ordovician formations and faunas of South Korea, Part X, Stratigraphy of the Chosen Group in Korea and South Manchuria and its relation to the Cambro-Ordovician formations of other areas, Section A, The Chosen Group of South Korea. Journal of the Faculty of Science, University of Tokyo, Section II, 16, 1-84.

Kobayashi, T., 1967, The Cambro-Ordovician formations and faunas of South Korea, Part X, stratigraphy of the Chosen group in Korea and South Manchuria and its relation to the Cambro-Ordovician formations of other areas, section C, the Cambrian of eastern Asia and other parts of the continent. Journal of the Faculty of Science, University of Tokyo, 16, 381-534.

Kobayashi, T., Yosimura, I., Iwaya, Y., and Hukasawa, T., 1942, The Yokusen geosyncline in the Chosen period - brief notes on the geologic history of the Yokusen orogenic zone, 1. Proceedings of the Imperial Academy of Tokyo, 18, 579-584.

Kuo, H.-C., Duan, J.-Y., and An, S.-L., 1982, Cambrian-Ordovician boundary in the North China Platform with descriptions of trilobites. Journal of Changchun College of Geology, 3, 9-28. (In Chinese with English summary)

Kwon, Y.K., Chough, S.K., Choi, D.K., and Lee, D.J., 2006, Sequence stratigraphy of the Taebaek Group (Cambrian-Ordovician), Mideast Korea. Sedimentary Geology, 192, 19-55.

Lake, P., 1906, A monograph of the British Cambrian trilobites, Part I. Monographs of the Palaeontographical Society of London, 1906, $1-28$.

Lazarenko, N.P., 1966, Biostratigraphy and some new trilobites from the Upper Cambrian of the Olenek Uplift and Kharaulakh Mountains. Nauchno-Issledovatel'skaya Institut Geologii Arktiki, Uchenye Zapiski, Paleontologiya i Biostratigrafiya, 11, 33-78. (in Russian)

Lee, J.G. and Choi, D.K., 1995, Late Cambrian Trilobites from the Machari Formation, Yeongweol-Machari area, Korea. Journal of the Paleontological Society of Korea, 11, 1-46.

Lee, J.G. and Choi, D.K., 1999a, Ontogeny of the Late Cambrian trilobite Olenus asiaticus Kobayashi, 1944 from the Machari Formation of Korea. Geosciences Journal, 3, 225-231.

Lee, D.-C. and Choi, D.K., 1999b, Ontogenetic changes of bacculae in
Korean asaphid trilobites and their taxonomic implications. Journal of Paleontology, 73, 1210-1213.

Lee, D.-C. and Chatterton, B.D.E., 2005, Protaspid ontogeny of Bolaspidella housensis (Order Ptychopariida, Class Trilobita), and other similar Cambrian protaspides. Transactions of the Royal Society of Edinburgh: Earth Sciences, 96, 21-41.

Lee, S.-B. and Choi, D.K., 2011, Dikelocephalid trilobites from the Eosaukia fauna (upper Furongian) of the Taebaek Group, Korea. Journal of Paleontology, 85, 279-297.

Lee, H.Y., Cheong, C.H., Lee, J.D., and Lee, J.S., 1980, Biostratigraphic and bioprovincial studies on trilobite fauna from the Joseon Supergroup of South Korea, with special consideration of trilobites from the Jigunsan Shale. Journal of National Academy of Sciences of Korea, 19, 111-131. (in Korean with English abstract)

Lin, J.L., Fuller, M., and Zhang, W.Y., 1985, Preliminary Phanerozoic polar wander paths for the North and South China blocks. Nature, 313, 444-449.

Lin, C., Yang, Q., and Li, S., 1995, Basin Filling and Evolution Analysis of Helan Aulacogen, Northwest China. Geological Publishing House, Beijing, 143 p. (in Chinese with English summary)

Linnarsson, J.G.O., 1869, Om Vestergötlands Cambriska och Siluriska aflagringar. Kongliga Svenska Vetenskaps-Akademiens Handlingar, $8,1-89$.

Lu, Y.-H., 1950, On the genus Redlichia, with description of its new species. Geological Review, 15, 157-170. (in Chinese)

Lu, Y.-H., 1957, Trilobita. In: Institute of Geology and Palaeontology, Academia Sinica (ed.), Index Fossils of China, Invertebrata, III. Geological Publishing House, Beijing, p. 249-294. (in Chinese)

Lu, Y.-H. and Lin, H.-L., 1984, Late Late Cambrian and earliest Ordovician trilobites of Jiangshan-Changshan area, Zhejiang. In: Nanjing Institute of Geology and Palaeontology (ed.), Stratigraphy and Palaeontology of Systematic Boundaries in China, Cambrian-Ordovician Boundary, 1. Anhui Science and Technology Publishing House, Hefei, p. 45-164.

Lu, Y.-H. and Qian, Y.-Y., 1983, New zonation and correlation of the Upper Cambrian Changshanian Stage in North China. Acta Palaeontologica Sinica, 22, 235-254. (in Chinese with English summary)

Lu, Y.H., Zhu, Z.L., Qian, Y.Y., Lin, H.L., Zhou, Z.Y., and Yuan, K.X., 1974, Bio-environmental control hypothesis and its application to Cambrian biostratigraphy and palaeozoogeography. Memoir of the Nanjing Institute of Geology and Palaeontology, Academia Sinica, 5, 27-110. (in Chinese with English summary)

McKenzie, N.R., Hughes, N.C., Myrow, P.M., Choi, D.K., and Park, T.Y., 2011, Trilobites and zircons link north China with the eastern Himalaya during the Cambrian. Geology, 39, 591-594.

Meng, X.H. and Ge, M., 2004, Sequences, Events and Evolution of the Sino-Korean Plate - Study on Astronomic Cyclic Responses in Sedimentation and Their Significance. Science Press, Beijing, $483 \mathrm{p}$.

Meng, X., Ge, M., and Tucker, M.E., 1997, Sequence stratigraphy, sealevel changes and depositional systems in the Cambro-Ordovician of the North China carbonate platform. Sedimentary Geology, 114, 189-222.

Metcalfe, I., 2006, Palaeozoic and Mesozoic tectonic evolution and palaeogeography of East Asian crustal fragments: The Korean Peninsula in context. Gondwana Research, 9, 24-46.

Metcalfe, I., 2013, Gondwana dispersion and Asian accretion: Tectonic 
and palaeogeographic evolution of eastern Tethys. Journal of Asian Earth Sciences, 66, 1-33.

Monke, H., 1903, Beiträge zur Geologie von Schantung. Part 1: Obercambrische Trilobiten von Yen-tsy-yai. Jahrbuch der Königliche Preussische Geologische Landesanstalt, Berlin, 23, 103-151.

Öpik, A.A., 1961, Alimentary caeca of agnostoids and other trilobites. Palaeontology, 3, 410-438.

Öpik, A.A., 1967, The Mindyallan fauna of north-western Queensland. Bulletin of the Bureau of Mineral Resources, Geology and Geophysics, 74, 1-404.

Palmer, A.R., 1968, Cambrian trilobites of east-central Alaska. US Geological Survey, Professional Paper, 559B, 1-115.

Park, T.-Y.S., (in press), Ontogeny of the two co-occurring middle Furongian (late Cambrian) shumardiid trilobites and the protaspid morphology of shumardiids. Geological Magazine.

Park, T.-Y. and Choi D.K, 2009, Post-embryonic development of the Furongian (late Cambrian) trilobite Tsinania canens: implications for life mode and phylogeny. Evolution \& Development, 11, 441455

Park, T.-Y. and Choi, D.K., 2010a, Two middle Cambrian diceratocephalid trilobites, Cyclolorenzella convexa and Diceratocephalus cornutus, from Korea: development and functional morphology. Lethaia, 43, 73-87.

Park, T.-Y. and Choi, D.K., 2010b, Ontogeny and ventral median suture of the ptychaspidid trilobite Asioptychaspis subglobosa (Sun, 1924) from the Furongian (Upper Cambrian) Hwajeol Formation, Korea. Journal of Paleontology, 84, 309-320.

Park, T.-Y. and Choi, D.K., 2011a, Ontogeny of the Furongian (late Cambrian) remopleuridioid trilobite Haniwa quadrata Kobayashi, 1933 from Korea: implications for trilobite taxonomy. Geological Magazine, 148, 288-303.

Park T.-Y. and Choi D.K., 2011b, Trilobite faunal successions across the base of the Furongian Series in the Taebaek Group, Taebaeksan Basin, Korea. Geobios, 44, 481-498.

Park, T.-Y. and Choi, D.K., 2011c, Constraints on using ontogenetic data for trilobite phylogeny. Lethaia, 44, 250-254.

Park, T.-Y. and Choi, D.K., 2012a, Middle Furongian (late Cambrian) shumardiids from the Sesong Formation, Taebaek Group, Korea. Journal of Paleontology, 86, 51-59.

Park, T.-Y. and Choi, D.K., 2012b, Recent achievements on the ontogenetic studies of the trilobites from the Taebaek Group: contributions to the phylogeny of trilobites. Journal of the Paleontological Society of Korea, 28, 1-9. (in Korean with English summary)

Park, T.-Y.S. and Kihm, J.-H., 2015a, Furongian (late Cambrian) trilobites from the Asioptychaspis subglobosa Zone of the Hwajeol Formation, Korea. Alcheringa, 39, 181-199.

Park, T.-Y.S. and Kihm, J.-H., 2015b, Post-embryonic development of the Early Ordovician (ca. $480 \mathrm{Ma}$ ) trilobite Apatokephalus latilimbatus Peng, 1990 and the evolution of metamorphosis. Evolution \& Development, 17, 289-301.

Park, T.-Y., Sohn, J.W., and Choi, D.K., 2012, Middle Furongian (late Cambrian) polymerid trilobites from the upper part of the Sesong Formation, Taebaeksan Basin, Korea. Geosciences Journal, 16, 381-398.

Park, T.-Y., Kihm, J.-H., and Choi, D.K., 2013, Late middle Cambrian (Cambrian Series 3) trilobite faunas from the lowermost part of the
Sesong Formation, Korea and their correlation with North China. Journal of Paleontology, 87, 991-1003.

Park, T.-Y.S., Kihm, J.-H., Kang, I., and Choi, D.K., 2014, Ontogeny of a new species of the Cambrian Series 3 (middle Cambrian) trilobite genus Liostracina Monke, 1903 from North China and the taxonomic position of the Superfamily Trinucleoidea. Journal of Paleontology, 88, 395-402.

Park, T.-Y.S., Kihm, J.-H., Woo, J., Kim, Y.-H.G., and Lee, J.I., 2016, Ontogeny of the Furongian (late Cambrian) trilobite Proceratopyge cf. P.lata Whitehouse from northern Victoria Land, Antarctica, and the evolution of metamorphosis in trilobites. Palaeontology, 59, 657-670.

Peng, S., 1990, Tremadocian stratigraphy and trilobite fauna of northwestern Hunan. 2. Trilobites from the Penjiazui Formation and the Madaoyu Formation in the Jiangnan Slope belt. Beringeria, 2, 55-171.

Peng, S.-C., 1992, Upper Cambrian biostratigraphy and trilobite faunas of the Cili-Taoyuan area, northwestern Hunan, China. Memoir of the Association of Australian Paleontologists, 13, 1-119.

Peng, S.-C., Babcock L.E., and Lin, H., 2004, Polymerid Trilobites from the Cambrian of Northwestern Hunan, China. Science Press, Beijing, v. 1, 333 p.; v. 2, 355 p.

Peng, S.-C., Babcock L.E., and Cooper R.A., 2012, The Cambrian Period. In: Gladstein, F.M., Ogg. J.G., Schmitz. M.D., and Ogg. G.M. (eds.), The Geologic Time Scale 2012. Elsevier, Amsterdam, p. $437-488$.

Qian, Y.-Y., 1985, Late Late Cambrian trilobites from the Tangcun Formation of Jingxian, southern Anhui. Palaeontologia Cathayana, 2, 137-167.

Qian, Y.-Y., 1994, Trilobites from middle Upper Cambrian (Changshan Stage) of north and northeast China. Palaeontologia Sinica, 183, 1-190. (in Chinese with English summary)

Qiu, H.-A., Lu, Y.-H., Zhu, Z.-L., Bi, D.-C., Lin, T.-R., Zhang, Q.-Z., Qian, Y.-Y., Ju, T.-Y., Han, N.-R., and Wei, X.-Z., 1983, Trilobita. In: Palaeontological Atlas of East China (1): Volume of Early Palaeozoic. Geological Publishing House, Beijing, p. 28-254. (in Chinese)

Raymond, P.E., 1924, New Upper Cambrian and Lower Ordovician trilobites from Vermont. Proceedings of the Boston Society of Natural History, 37, 389-466.

Reed, F.R.C., 1917, Ordovician and Silurian fossils from Yun-nan. Memoirs of the Geological Survey of India. Palaeontologia Indica, 6, 1-123.

Resser, C.E., 1938, Cambrian System (restricted) of the southern Appalachians. The Geological Society of America, Special Papers, 15, 1140.

Resser, C.E. and Endo R., 1937, Description of the fossils. Manchurian Science Museum Bulletin, 1, 103-301, 370-434.

Robison, R.A. and Pantoja-Alor J., 1968, Tremadocian trilobites from the Nochixtlan region, Oaxaca, Mexico. Journal of Paleontology, $42,767-800$.

Rozova, A.V., 1964, Biostratigraphy and description of trilobites of the Middle and Upper Cambrian of the northwest Siberian Platform. Akademiya Nauk SSSR, Sibiriskoe Otdelenie, Institut Geologii i Geofiziki. Moscow: Izdatelstvo "Nauka”. (in Russian)

Schrank, E., 1975, Kambrische Trilobiten der China-Kollecktion v. Richthofen, Teil 2: Die Fauna mit Kaolishania? quadriceps von Saimaki. Zeitschrift für Geologische Wissenschaften, 3, 591-619. 
Scotese, C.R. and McKerrow, W.S., 1990, Revised world maps and introduction. In: McKerrow, W.S. and Scotese, C.R. (eds.), Palaeozoic Palaeogeography and Biogeography. Memoris of the Geological Society, 12, p. 1-21.

Shergold, J.H., 1982, Idamean (Late Cambrian) trilobites, Burke River structural belt, western Queensland. Bulletin of the Bureau of Mineral Resources, Geology and Geophysics, 187, 1-69.

Shergold, J.H., 1991, The Pacoota Sandstone, Amadeus Basin, Northern Territory: stratigraphy and palaeontology. Bulletin of the Bureau of Mineral Resources, Geology and Geophysics, 237, 1-93.

Shergold, J.H., Jago, J., Cooper, R., and Laurie, J.R., 1985, The Cambrian System in Australia, Antarctica and New Zealand, correlation charts and explanatory notes. International Union of Geological Sciences, Publication No. 19, 85 p.

Shergold, J.H., Laurie, J.R., and Shergold, J.E., 2007, Cambrian and Early Ordovician trilobite taxonomy and biostratigraphy, Bonaparte Basin, Western Australia. Memoirs of the Association of Australasian Palaeontologists, 34, 17-86.

Sohn J.W. and Choi D.K., 2005, A Late Cambrian trilobite Hamashania from Korea. Alcheringa, 29, 195-203.

Sohn, J.W. and Choi, D.K., 2007, Furongian trilobites from the Asioptychaspis and Quadraticephalus zones of the Hwajeol Formation, Taebaeksan Basin, Korea. Geosciences Journal, 11, 297-314.

Squire, R.J., Campbell, I.H., Allen, C.M., and Wilson, C.J.L., 2006, Did the Transgondwanan Supermountains trigger the explosive radiation of animals on Earth? Earth and Planetary Science Letters, 250, 116-133.

Stubblefiled, C.J., 1926, Notes on the development of a trilobite, Shumardia pusilla (Sars). Linnean Society Journal of Zoology, 36, 345372.

Sun, X.-W., 1989, Cambrian agnostids from the North China Platform. Palaeontologia Cathayana, 4, 53-129.

Sun, Y.-C., 1924, Contribution to the Cambrian faunas of China. Palaeontologia Sinica, 1, 1-109.

Sun, Y.-C., 1935, The Upper Cambrian trilobite-faunas of North China. Palaeontologia Sinica, 7, 5-93.

Sun, Z., Xie, Q., and Yang, J., 1989, Ordos basin: a typical example of an unstable cratonic interior superimposed basin. In: Zhu, X. (ed.), Chinese Sedimentary Basins. Elsevier, New York, p. 63-75.

Troedsson, G.T., 1937, On the Cambro-Ordovician faunas of western Quruq-Tagh, eastern Tien Shan. Palaeontologia Sinica, 106, 1-74.

Tullberg, S.A., 1880, Om Agnostus-arterna i de Kambriska aflagringarne vid Andrarum. Sveriges Geologiska Undersökning (Series C), 42, 1-37.

Veevers, J.J., 2004, Gondwanaland from 650-500 Ma assembly through 320 Ma merger in Pangea to 185-100 Ma breakup: supercontinental tectonics via stratigraphy and radiometric dating. Earth-Science Reviews, 68, 1-132.

Waisfeld, B.G., Vaccari, N.E., Chatterton, B.D.E., and Edgecombe, G.D., 2001, Systematics of Shumardiidae (Trilobita), with new species from the Ordovician of Argentina. Journal of Paleontology, 75, 827-859.

Walcott, C.D., 1886, Second contribution to the studies on the Cambrian faunas of North America. United States Geological Survey
Bulletin, 29, 1-306.

Walcott, C.D., 1905, Cambrian faunas of China. Proceedings of the United States National Museum, 29, 1-106.

Walcott, C.D., 1906, Cambrian faunas of China. Proceedings of the United States National Museum, 30, 563-595.

Walcott, C.D., 1911, Cambrian faunas of China. Smithsonian Miscellaneous Collections, 57, 69-109.

Walcott, C.D., 1924, Cambrian geology and paleontology 5, no. 2, Cambrian and Lower Ozarkian trilobites. Smithsonian Miscellaneous Collections, 75, 53-60.

Whittington, H.B., 1957, The ontogeny of trilobites. Biological Reviews, $32,421-469$.

Whittington, H.B., 2007, Reflections on the classification of the Trilobita. In: Mikulic, D.G. and Landing, E. (eds.), Fabulous Fossils 300 Years of Worldwide Research on Trilobites. New York State Museum Bulletin, 507, p. 225-230.

Wu, Y.-B. and Zheng Y.-F., 2013, Tectonic evolution of a composite collision orogeny: an overview on the Qinling-Tongbai-HonganDabie-Sulu orogenic belt in central China. Gondwana Research, 23, 1402-1428.

Wu, L., Jia, D., Li, H., Deng, F., and Li, Y., 2010, Provenance of detrital zircons from the late Neoproterozoic to Ordovician sandstones of South China: implications for its continental affinity. Geological Magazine, 147, 974-980.

Yang, J.-L., 1982, Notes on the Middle Cambrian trilobite faunas from Duibian of Jiangshan, Zhejiang. Geological Review, 28, 299-307. (in Chinese with English abstract)

Yin, A. and Nie, S., 1996, A Phanerozoic palinspastic reconstruction of China and its neighboring regions. In: Yin, A. and Harrison, M. (eds.), The Tectonic Evolution of Asia. Cambridge University Press, Cambridge, p. 442-485.

Yosimura, I., 1940, Geology of the Neietsu District, Kogendo, Tyosen. Journal of the Geological Society of Japan, 47, 112-122. (in Japanese)

Zhang, W.-T. and Jell P.A., 1987, Cambrian Trilobites of North China, Chinese Cambrian Trilobites Housed in the Smithsonian Institution. Science Press, Beijing, 459 p.

Zhou, Z.-Y. and Zhang J.-L., 1978, Cambrian-Ordovician boundary of the Tangshan area with descriptions of the related trilobite fauna. Acta Palaeontologica Sinica, 17, 1-32. (in Chinese with English abstract)

Zhou, Z.-Y. and Zhang J.-L., 1985, Uppermost Cambrian and lowest Ordovician trilobites of North and Northeast China. In: Nanjing Institute of Geology and Palaeontology (ed.), Stratigraphy and Palaeontology of Systemic Boundaries in China, Cambrian-Ordovician Boundary (2). Anhui Science and Technology Publishing House, Hefei, p. 63-163.

Zhou, Z.-Y., Zhou, Z.Q., and Zhang, J.L., 1989, Ordovician trilobite biofacies of North China platform and its western marginal area. Acta Palaeontologica Sinica, 28, 296-313.

Zhu, Z.-L. and Wittke H.W., 1989, Upper Cambrian trilobites from Tangshan, Hebei Province, North China. Palaeontologica Cathayana, 4, 199-259. 